\title{
31. DEPTH TRENDS IN PHOSPHORUS DISTRIBUTION AND C:N:P RATIOS OF ORGANIC MATTER IN AMAZON FAN SEDIMENTS: INDICES OF ORGANIC MATTER SOURCE AND BURIAL HISTORY ${ }^{1}$
}

\author{
K.C. Ruttenberg ${ }^{2}$ and M.A. Goñi ${ }^{3}$
}

\begin{abstract}
Solid-phase total, inorganic, and organic phosphorus (TP, IP, and OP) concentrations and C:N:P ratios of sediment organic matter from Sites 932 and 942 on the Amazon Fan, collected during Ocean Drilling Program Leg 155, are presented here. Depth trends in phosphorus distribution are consistent with lithostratigraphic evidence for variations in the supply of terrestrially derived detritus, display evidence of remineralization of OP with depth, and are suggestive of reincorporation of remineralized OP by secondary authigenic phosphate minerals. The diagenetic transformation of phosphorus suggested by the solidphase data is supported by pore-water data. Variations in elemental C:N:P ratios with depth are interpreted as resulting predominantly from changing proportions of terrestrially derived vs. marine-derived organic matter. The timing of these shifts is consistent with those predicted on the basis of lithostratigraphic evidence, and other organic geochemical data, which suggest that these ratios may be used as indicators of organic-matter source. This conclusion is supported by the systematic correlation of organic matter-derived $\mathrm{C}: \mathrm{N}: \mathrm{P}$ elemental ratios with the carbon isotopic composition of organic matter from these sediments. Taken together, the lithostratigraphic, elemental ratio, and carbon isotopic composition data, are consistent with shifts between the accumulation of dominantly terrestrially derived detritus on the Amazon Fan during times of low sea-level stand, giving way to dominantly hemipelagic sedimentation during times of high sea-level stand. The oxygen isotope stratigraphy developed for Sites 932 and 942 is consistent with the timing of sea-level change inferred from the C:N:P elemental ratios and carbon isotopic signatures of organic matter in these sediments.
\end{abstract}

\section{INTRODUCTION}

Rivers are the main source of phosphorus (P) to the oceans, and the Amazon River has been a globally significant river since the Miocene. The sedimentary $\mathrm{P}$ record reflects two processes: riverine input, and the efficiency of $\mathrm{P}$ sequestration by marine sediments. To effectively interpret $\mathrm{P}$ burial in sediments, these two processes must be resolved. Deposition of organic matter is a quantitatively important mechanism of P delivery to sediments (Ruttenberg, 1993). The two major sources of organic matter to marine sediments are terrestrial and marine plants; each have distinctive C:N:P ratios. Marine phytoplankton have a mean molar organic C:P ratio of 106:1, and a mean molar C:N ratio of 6.6:1 (Redfield et al., 1963). In contrast, terrestrial plants are relatively impoverished in $\mathrm{P}$ and $\mathrm{N}$, with characteristic $\mathrm{C}: \mathrm{P}$ ratios ranging up to or exceeding 800 , and $\mathrm{C}: \mathrm{N}$ ratios ranging up to or exceeding 1000 (Likens et al., 1981). If organic matter in marine sediments from river-dominated coastal regimes can be characterized as a two-end-member mixture of terrestrial and marine phytodetritus, sediments that are dominated by terrestrial organic matter should be characterized by high organic C:P and C:N ratios, whereas sediments in which the organic matter is dominated by marine plants should be relatively enriched in organic phosphorus (OP) and organic $\mathrm{N}$ (lower ratios). The importance of making this distinction lies not only in understanding the sources of organic matter to marine sediments, but also in assessing the overall reactivity of the sediments. Diagenetic reactions are fueled by the microbial remineralization of organic matter. These reactions can result in changes in the redox state of sedi-

${ }^{1}$ Flood, R.D., Piper, D.J.W., Klaus, A., and Peterson, L.C. (Eds.), 1997. Proc. ODP, Sci. Results, 155: College Station, TX (Ocean Drilling Program).

${ }^{2}$ Department of Marine Chemistry and Geochemistry, Woods Hole Oceanographic Institution, Woods Hole, MA 02543, U.S.A

${ }^{3}$ Department of Geology, Program in Marine Sciences, University of South Carolina, Columbia, SC 29208, U.S.A. ments, in the formation of secondary authigenic minerals, and the progressive alteration of organic matter from labile to more refractory forms. These diagenetic transformations can greatly alter the nature of sediments from their initial state. It is crucial, therefore, to ascertain the magnitude of diagenetic modification undergone by sediments in order to assess the degree to which they still yield information on the original conditions of deposition.

In this paper, we present solid-phase $\mathrm{P}$-speciation data and $\mathrm{C}: \mathrm{N}: \mathrm{P}$ ratios of sediment organic matter from Sites 932 and 942 on the Amazon Fan, collected during Ocean Drilling Program (ODP) Leg 155. The fan has not been active during the Holocene high sea-level stand. During glacial lowstands, however, the Amazon River crossed the emerged shelf and discharged sediments in deeper water, feeding the Amazon Fan. The cores collected on Leg 155 extend back through isotopic Stage 5 and into Stage 6 (>120 ka; Flood, Piper, Klaus, et al., 1995 ) and, therefore, sample several oscillations in sea level associated with glacial-interglacial transitions. The nature of sediment deposited on the fan changes as a function of sea level due to shifts in the locus of Amazon River discharge. During glacial lowstands, terrigenous material carried by the river discharged onto the fan. During periods of high sea-level, most of the material carried by the Amazon River is trapped on the shelf (Nittrouer et al., 1991), and deposition on the fan is dominated by marine-derived material. In this paper, phosphorus concentration data and $\mathrm{C}: \mathrm{N}: \mathrm{P}$ ratios are used to make a first-order assessment of the relative proportions of organic matter derived from terrestrial vs. marine sources. Also discussed is the degree to which these data are consistent with other indices of organic matter source, principally carbon isotopic signatures, and the extent to which diagenetic overprinting of the initial deposition signal impairs our ability to assess organic matter source. The timing of shifts in organic matter source inferred from $\mathrm{C}: \mathrm{N}: \mathrm{P}$ ratios and the carbon isotopic composition of organic matter are compared to changes in sea level predicted on the basis of oxygen isotope stratigraphy at these sites. 


\section{METHODOLOGY}

\section{Sample Collection and Preparation}

Seventeen samples were taken at $\approx 10$-cm intervals in Hole $932 \mathrm{~A}$ spanning 3.57 to 163.63 meters below seafloor (mbsf); one sample was taken from Hole 932B at 0.82 mbsf (Table 1). Twenty samples were taken at $\approx 10-\mathrm{cm}$ intervals in Hole $942 \mathrm{~A}$, spanning 1.57 to $169.71 \mathrm{mbsf}$, and six samples from Hole 942C (Table 2). Samples were stored frozen until freeze-dried in the laboratory. For additional details on sample collection, see Goñi (this volume). Freeze-dried samples were ground to pass through a $125-\mu \mathrm{m}$ mesh sieve.

\section{Analytical Methods}

Bulk sediment total phosphorus (TP) and inorganic phosphorus (IP) were determined by leaching two sample splits in $1 \mathrm{M} \mathrm{HCl}$, the TP split initially having been ashed at $550^{\circ} \mathrm{C}$. OP was determined by difference (TP-IP) (Aspila et al., 1976; Ruttenberg, 1992). The error in reproducibility of TP, IP, and OP is better than $1.5 \%, 1.5 \%$, and $5.6 \%$, respectively. The efficiency of the ashing method for quantifying TP was verified in Ruttenberg (1992), where TP recoveries obtained from a variety of pure plant tissues and sediments via the ashing method was proven comparable to recoveries obtained using the well-accepted method of fuming nitric/perchloric acid digestion (Black, 1965; Strickland and Parsons, 1972). Since OP is derived from the difference of two independently measured parameters (TP and IP), however, uncertainties exist in the accuracy of OP that may exceed those associated with the analytical reproducibility of OP, especially if TP and IP are of similar magnitude. Additionally, potential artifacts due to incomplete IP recovery from clays and ferric iron phases during $1 \mathrm{M} \mathrm{HCl}$ extraction of the unashed split can lead to underestimates of IP (Mach et al., 1987; Ruttenberg, 1992), and a portion of the $\mathrm{P}$ associated with these recalcitrant phases may be extractable in $1 \mathrm{M} \mathrm{HCl}$ after ashing at $550^{\circ} \mathrm{C}$, resulting in the overestimation of OP (Ruttenberg, unpubl. data). Some labile forms of OP may be extracted by $1 \mathrm{M} \mathrm{HCl}$ from the unashed split, which could result in overestimates of IP, and underestimates of OP. A portion of the HCl-

Table 1. Elemental composition of sediments from Site 932.

\begin{tabular}{|c|c|c|c|c|c|c|c|c|c|c|}
\hline $\begin{array}{l}\text { Core, section, } \\
\text { interval }(\mathrm{cm})\end{array}$ & $\begin{array}{l}\text { Depth } \\
\text { (mbsf) }\end{array}$ & Subunit & $\begin{array}{c}\mathrm{TP} \\
(\mu \mathrm{mol} / \mathrm{g})\end{array}$ & $\begin{array}{c}\text { IP } \\
(\mu \mathrm{mol} / \mathrm{g})\end{array}$ & $\begin{array}{c}\text { OP } \\
(\mu \mathrm{mol} / \mathrm{g})\end{array}$ & $\begin{array}{c}\text { TOC } \\
(\mathrm{mmol} / \mathrm{g})\end{array}$ & $\begin{array}{c}\mathrm{TN} \\
(\mathrm{mmol} / \mathrm{g})\end{array}$ & $\begin{array}{l}\text { OC:OP } \\
\text { (molar) }\end{array}$ & $\begin{array}{l}\text { OC:TN } \\
\text { (molar) }\end{array}$ & $\begin{array}{l}\text { TN:OP } \\
\text { (molar) }\end{array}$ \\
\hline $\begin{array}{l}155-932 \mathrm{~B}- \\
1 \mathrm{H}-1,82-88\end{array}$ & 0.82 & IIA & 16.76 & 11.83 & 4.93 & 0.48 & 0.06 & 98 & 8 & 12 \\
\hline $\begin{array}{l}155-932 \mathrm{~A}- \\
1 \mathrm{H}-3,57-67\end{array}$ & 3.57 & IIA & 18.69 & 13.64 & 5.05 & 0.58 & 0.07 & 116 & 8 & 14 \\
\hline $2 \mathrm{H}-4,104-114$ & 11.54 & IIA & 28.79 & 25.03 & 3.76 & 0.58 & 0.08 & 153 & 7 & 21 \\
\hline $3 \mathrm{H}-4,105-109$ & 21.05 & IIA & 26.30 & 22.04 & 4.26 & 0.63 & 0.08 & 147 & 8 & 18 \\
\hline $5 \mathrm{H}-4,106-116$ & 40.06 & IIA & 21.71 & 17.41 & 4.30 & 0.66 & 0.09 & 153 & 8 & 20 \\
\hline $6 \mathrm{H}-4,100-110$ & 49.50 & IIB & 24.87 & 21.36 & 3.51 & 0.88 & 0.09 & 252 & 10 & 24 \\
\hline $7 \mathrm{H}-4,89-99$ & 58.89 & IIB & 24.23 & 20.23 & 4.00 & 0.88 & 0.10 & 221 & 9 & 25 \\
\hline $8 \mathrm{H}-4,30-40$ & 64.35 & IIB & 22.37 & 18.82 & 3.55 & 0.84 & 0.09 & 237 & 9 & 26 \\
\hline $9 \mathrm{H}-4,110-120$ & 77.53 & IIB & 26.00 & 22.28 & 3.72 & 0.85 & 0.09 & 228 & 9 & 25 \\
\hline $10 \mathrm{H}-5,43-54$ & 86.90 & IIB & 22.27 & 18.96 & 3.31 & 0.78 & 0.09 & 237 & 9 & 26 \\
\hline $11 X-4,87-97$ & 96.76 & IIB & 25.42 & 22.28 & 3.14 & 0.78 & 0.09 & 249 & 8 & 30 \\
\hline $12 \mathrm{X}-4,31-41$ & 105.81 & IIB & 22.09 & 19.26 & 2.83 & 0.83 & 0.09 & 292 & 10 & 30 \\
\hline $13 \mathrm{X}-3,97-107$ & 114.57 & IIB & 22.22 & 18.74 & 3.48 & 0.81 & 0.09 & 232 & 9 & 25 \\
\hline $14 X-4,57-67$ & 125.37 & IIB & 22.55 & 19.86 & 2.69 & 0.76 & 0.09 & 282 & 8 & 35 \\
\hline $15 X-4,63-73$ & 135.13 & IIB & 21.46 & 18.68 & 2.78 & 0.70 & 0.09 & 252 & 8 & 33 \\
\hline $16 X-3,75-85$ & 143.45 & IIB & 22.19 & 20.05 & 2.14 & 0.68 & 0.07 & 315 & 9 & 33 \\
\hline $17 \mathrm{X}-3,107-111$ & 153.27 & IIB & 21.60 & 18.51 & 3.09 & 0.67 & 0.08 & 216 & 8 & 25 \\
\hline $18 \mathrm{X}-4,43-54$ & 163.63 & IIB & 21.36 & 18.35 & 3.01 & 0.66 & 0.08 & 219 & 8 & 26 \\
\hline
\end{tabular}

Notes: $\mathrm{TP}=$ total phosphorus; $\mathrm{IP}=$ inorganic phosphorus; $\mathrm{OP}=$ organic phosphorus; $\mathrm{TOC}=$ total organic carbon; $\mathrm{TN}=$ total nitrogen; $\mathrm{OC}$ : $\mathrm{OP}=$ organic carbon/organic phosphorus ratio; $\mathrm{OC}: \mathrm{TN}=$ organic carbon/total nitrogen ratio; TN:OP = total nitrogen/organic phosphorus ratio.

Table 2. Elemental composition of sediments from Site 942.

\begin{tabular}{|c|c|c|c|c|c|c|c|c|c|c|c|}
\hline Hole & $\begin{array}{l}\text { Core, section, } \\
\text { interval }(\mathrm{cm})\end{array}$ & $\begin{array}{l}\text { Depth } \\
\text { (mbsf) }\end{array}$ & $\begin{array}{c}\text { Unit/ } \\
\text { subunit }\end{array}$ & $\begin{array}{c}\mathrm{TP} \\
(\mu \mathrm{mol} / \mathrm{g})\end{array}$ & $\begin{array}{c}\mathrm{IP} \\
(\mu \mathrm{mol} / \mathrm{g})\end{array}$ & $\begin{array}{c}\mathrm{OP} \\
(\mu \mathrm{mol} / \mathrm{g})\end{array}$ & $\begin{array}{c}\text { TOC } \\
(\mathrm{mmol} / \mathrm{g})\end{array}$ & $\begin{array}{c}\mathrm{TN} \\
(\mathrm{mmol} / \mathrm{g})\end{array}$ & $\begin{array}{l}\text { OC:OP } \\
\text { (molar) }\end{array}$ & $\begin{array}{l}\text { OC:TN } \\
\text { (molar) }\end{array}$ & $\begin{array}{l}\text { TN:OP } \\
\text { (molar) }\end{array}$ \\
\hline $942 \mathrm{C}$ & $1 \mathrm{H}-1,50-56$ & 0.50 & I & 16.40 & 11.46 & 4.94 & 0.27 & 0.08 & 54 & 3 & 16 \\
\hline $942 \mathrm{C}$ & $1 \mathrm{H}-1,83-88$ & 0.83 & IIA & 36.07 & 30.11 & 5.96 & 0.43 & 0.06 & 71 & 7 & 11 \\
\hline $942 \mathrm{C}$ & $1 \mathrm{H}-1,98-103$ & 0.98 & IIA & 11.13 & 9.22 & 1.91 & 0.56 & 0.09 & 292 & 7 & 45 \\
\hline $942 \mathrm{~A}$ & $1 \mathrm{H}-2,7-17$ & 1.57 & IIA & 15.86 & 10.07 & 5.79 & 0.70 & 0.08 & 121 & 9 & 14 \\
\hline $942 \mathrm{~A}$ & $2 \mathrm{H}-4,38-48$ & 8.68 & IIA & 21.79 & 15.36 & 6.43 & 0.59 & 0.07 & 92 & 8 & 11 \\
\hline $942 \mathrm{C}$ & $2 \mathrm{H}-4,66-72$ & 9.46 & IIA & 9.68 & 7.96 & 1.72 & 0.06 & 0.03 & 34 & 2 & 17 \\
\hline $942 \mathrm{~A}$ & $3 \mathrm{H}-4,38-48$ & 18.18 & IIA & 19.29 & 13.82 & 5.47 & 0.65 & 0.08 & 119 & 8 & 14 \\
\hline $942 \mathrm{~A}$ & $4 \mathrm{H}-4,50-60$ & 27.80 & IIB & 12.77 & 10.06 & 2.71 & 0.42 & 0.06 & 154 & 7 & 21 \\
\hline $942 \mathrm{~A}$ & $5 \mathrm{H}-4,77-87$ & 37.31 & IIIB & 22.71 & 18.79 & 3.92 & 0.58 & 0.09 & 149 & 7 & 22 \\
\hline $942 \mathrm{~A}$ & $6 \mathrm{H}-1,35-42$ & 42.15 & IVB & 14.97 & 10.98 & 3.99 & 0.43 & 0.09 & 109 & 5 & 21 \\
\hline $942 \mathrm{~A}$ & $7 \mathrm{H}-6,14-24$ & 58.94 & IVB & 14.73 & 11.21 & 3.53 & 0.41 & 0.06 & 116 & 7 & 16 \\
\hline $942 \mathrm{C}$ & $5 \mathrm{H}-1,21-27$ & 62.21 & IVB & 23.90 & 18.83 & 5.07 & 0.20 & 0.06 & 39 & 3 & 13 \\
\hline $942 \mathrm{C}$ & $5 \mathrm{H}-1,84-90$ & 62.84 & IVB & 16.80 & 13.62 & 3.18 & 0.49 & 0.07 & 155 & 7 & 22 \\
\hline $942 \mathrm{~A}$ & $8 \mathrm{H}-5,65-71$ & 67.45 & VI & 17.64 & 13.84 & 3.80 & 0.60 & 0.09 & 158 & 7 & 23 \\
\hline $942 \mathrm{~A}$ & $9 \mathrm{H}-4,36-46$ & 73.03 & VI & 21.73 & 17.68 & 4.04 & 0.74 & 0.08 & 183 & 9 & 19 \\
\hline $942 \mathrm{~A}$ & $10 \mathrm{H}-5,75-85$ & 86.55 & VI & 23.11 & 19.74 & 3.36 & 0.73 & 0.09 & 216 & 8 & 25 \\
\hline $942 \mathrm{~A}$ & $11 \mathrm{H}-5,12-22$ & 94.05 & VI & 23.38 & 19.80 & 3.58 & 0.78 & 0.09 & 219 & 8 & 26 \\
\hline $942 \mathrm{~A}$ & $12 \mathrm{H}-3,40-50$ & 101.99 & VI & 24.02 & 20.50 & 3.52 & 0.76 & 0.09 & 215 & 9 & 24 \\
\hline $942 \mathrm{~A}$ & $13 X-3,46-56$ & 107.46 & VI & 23.62 & 20.07 & 3.55 & 0.79 & 0.09 & 223 & 9 & 24 \\
\hline $942 \mathrm{~A}$ & $14 \mathrm{X}-2,41-51$ & 112.01 & VI & 24.97 & 22.44 & 2.53 & 0.79 & 0.09 & 313 & 9 & 34 \\
\hline $942 \mathrm{~A}$ & $15 X-3,35-45$ & 123.05 & VI & 22.54 & 18.83 & 3.72 & 0.85 & 0.09 & 229 & 9 & 25 \\
\hline $942 \mathrm{~A}$ & $16 X-4,77-87$ & 134.57 & VI & 22.70 & 19.25 & 3.45 & 0.87 & 0.09 & 251 & 9 & 27 \\
\hline $942 \mathrm{~A}$ & $17 \mathrm{X}-4,80-90$ & 144.30 & VI & 23.27 & 21.47 & 1.80 & 0.73 & 0.09 & 406 & 8 & 51 \\
\hline $942 \mathrm{~A}$ & $18 X-4,54-64$ & 153.64 & VI & 23.71 & 20.36 & 3.35 & 0.91 & 0.10 & 271 & 9 & 30 \\
\hline $942 \mathrm{~A}$ & $19 \mathrm{X}-4,38-48$ & 163.18 & VI & 24.87 & 21.73 & 3.14 & 0.91 & 0.10 & 289 & 9 & 32 \\
\hline $942 \mathrm{~A}$ & $20 \mathrm{X}-2,31-41$ & 169.71 & VI & 25.07 & 21.84 & 3.23 & 0.86 & 0.10 & 266 & 9 & 31 \\
\hline
\end{tabular}

Note: Abbreviations as in Table 1. 


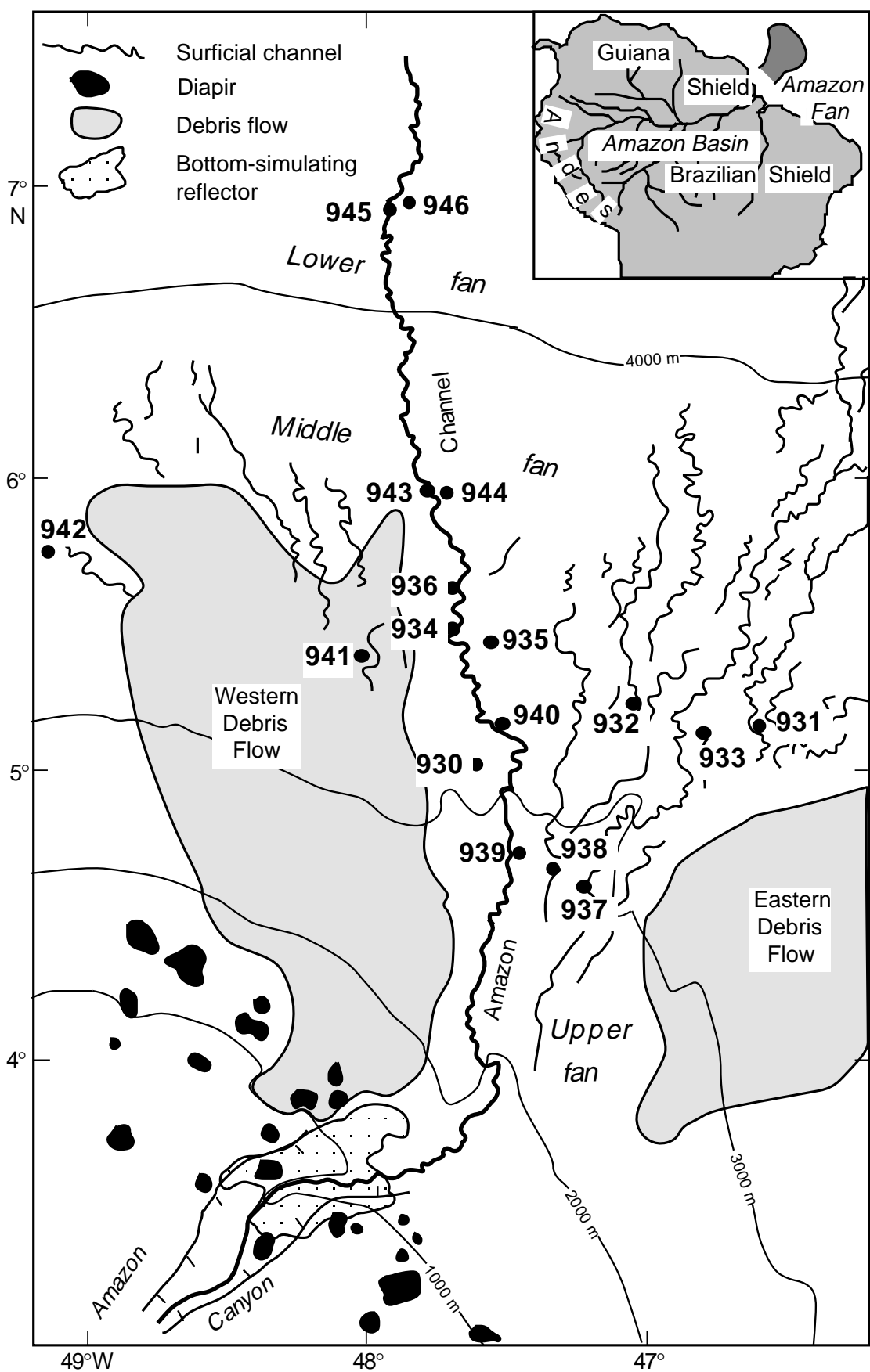

Figure 1. Location map of ODP Leg 155 coring sites on the Amazon Fan. From Flood et al., 1995; modified from Damuth et al., 1988, and Manley and Flood, 1988. extractable OP derived from the unashed split is not hydrolyzed, however, which significantly reduces this affect for both OP and IP (Ruttenberg, 1992). The shortcomings of the ashing method just articulated can largely be avoided by using the more complex SEDEX method (Ruttenberg, 1992). Yet, the ease and rapidity of the ashing method, relative to the SEDEX method, recommends it for preliminary reconnaissance studies such as the current study.

Total N (TN) was determined on bulk sediment samples using a Perkin Elmer model 2400 CHN Elemental Analyzer. Organic C (OC) was determined as the difference between total $\mathrm{C}$ (TC) of bulk sediment determined by $\mathrm{CHN}$ analyzer, and inorganic C (IC) of bulk sediment determined coulometrically (Ostermann et al., 1990), as the quantity of $\mathrm{CO}_{2}$ generated upon sample acidification with $100 \%$ $\mathrm{H}_{3} \mathrm{PO}_{4}$. The average mean deviations of $\mathrm{TC}$ and $\mathrm{TN}$ was $\pm 2 \%$, and the precision of IC measurements is better than $1 \%$ (Goñi, this volume). Stable carbon isotopic compositions of total organic carbon are from
Goñi (this volume) and are reported here relative to the PDB carbonate standard in the parts per thousand notation $\left(\delta^{13} \mathrm{C}_{\mathrm{TOC}} \%\right.$ o).

\section{DESCRIPTION OF SITES}

\section{Site 932}

Site 932 is located on the eastern part of the Amazon Fan (Fig. 1), on a flat terrace $200 \mathrm{~m}$ east of the western levee crest of abandoned Channel-levee-System 6B (Flood, Piper, Klaus, et al., 1995). Two lithologic units are recognized at Site 932: Unit I is a tan-brown Holocene calcareous (up to $50 \% \mathrm{CaCO}_{3}$ ) mud; Unit II is a terrigenous dark olive gray to very dark gray upper Pleistocene sediment, with uniformly low carbonate $(<3 \%)$ throughout, and interbedded laminae of silt and very fine sand. Unit II is subdivided into Subunits IIA and IIB on the basis of the frequency of sand and silt laminae and associ- 
A

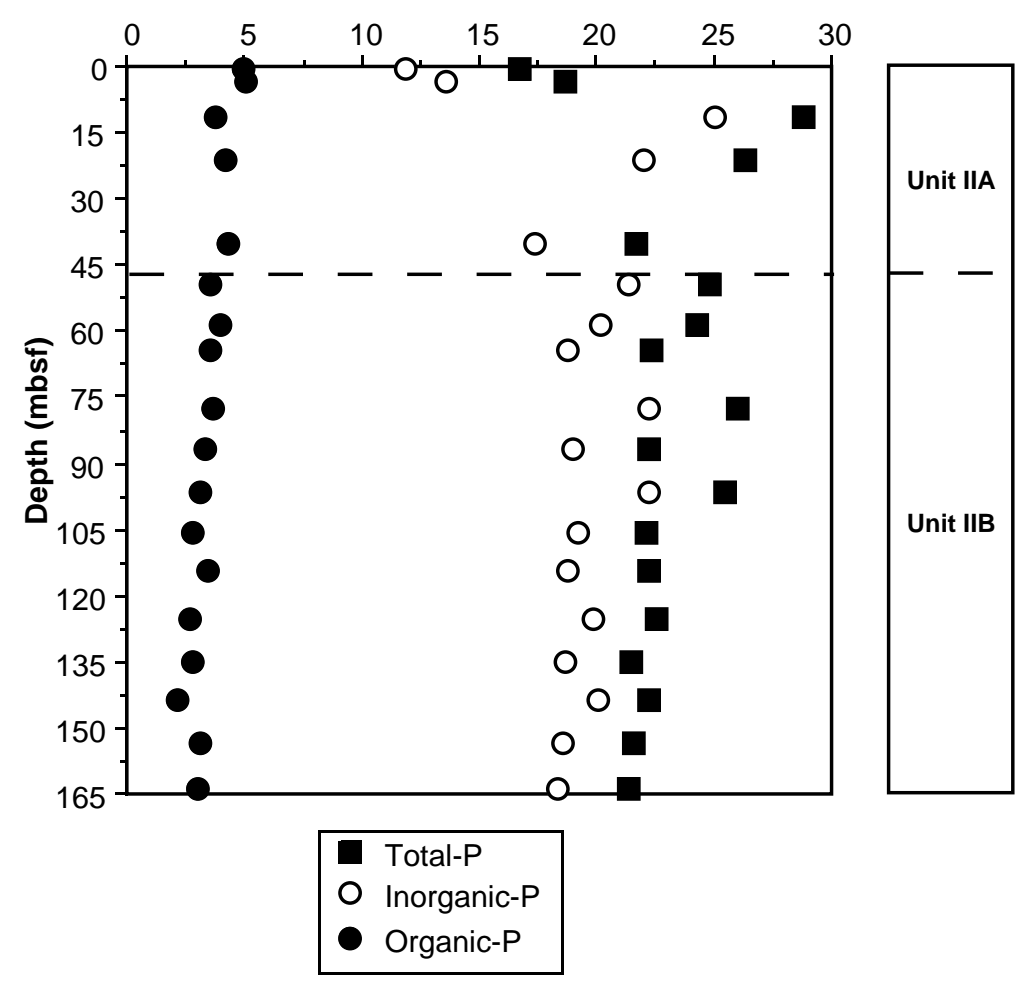

B

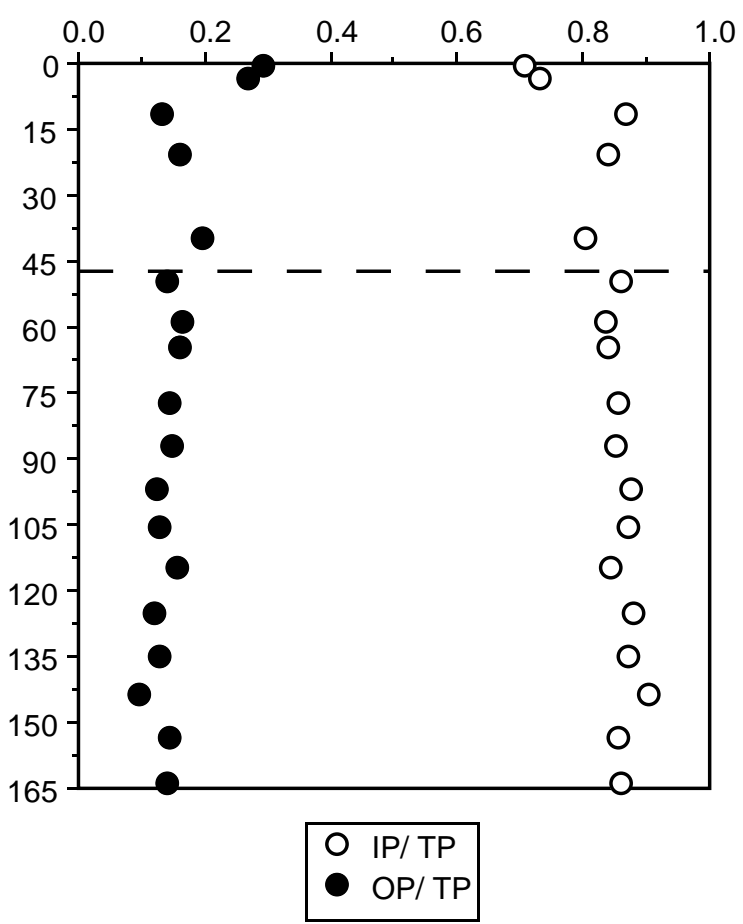

Figure 2. Depth profiles of solid-phase P distribution for Site 932. A. Concentration of total, inorganic, and organic P (TP, IP, and OP). B. Distribution of IP and OP expressed as the fraction of TP: IP/TP and OP/TP. Lithostratigraphic units are shown in the central panel, and unit boundaries are indicated by the dashed line.

ated black mottling and banding. Discrete laminae and beds of silt and silty-sand, often displaying upward grading from fine sand to silt to mud, occur in Subunit IIB. These bands increase in thickness and frequency downhole, especially below 130 mbsf. Black banding occurs at 1 - to $3-\mathrm{cm}$ intervals, sometimes with the aspect of varves (Flood, Piper, Klaus, et al., 1995). These features have been interpreted as reflecting overbank deposition by turbidity currents during a period when Channel-levee 6B was active. The boundary between Subunits IIB and IIA is characterized by alternating zones of color banding and mottling, believed to record the gradual transition from channel-levee activity to regional hemipelagic deposition, with Channel-levee 6B becoming inactive. Rare sand and silt laminae in Subunit IIA, combined with moderate-to-extensive bioturbation reflecting low sedimentation rates, support this interpretation. The change from black color banding characteristic of Subunit IIB to black mottling in Subunit IIA appears to be related to more prevalent bioturbation in Subunit IIA. Disturbed sections of sediment, possibly reflecting levee failure events and consequent debris flows or slumping, are observed in the intervals 40.81 to $42.10 \mathrm{mbsf}$ and 120.5 to 130.0 mbsf (Flood, Piper, Klaus, et al., 1995). Unit I marks the abrupt decrease of terrigenous sediment supply as a result of a rise in sea level (Flood, Piper, Klaus, et al., 1995). Primary age control for Site 932 is provided by the Lake Mungo paleomagnetic excursion (30 ka), which was observed at 25 mbsf, and the $Y_{P \text {. obliquiloculata }}$ datum (40 ka) at 44 mbsf (Flood, Piper, Klaus, et al., 1995). A more detailed age model for this site is presented in Maslin et al. (this volume). Our study is limited to sediments from Unit II; the calcareous Holocene mud samples of Unit I were not accessible for this study.

\section{Site 942}

Site 942 , the most westerly locality drilled on Leg 155 , is located on the crest of an abandoned levee west of the main portion of the middle Amazon Fan (Fig. 1). Site 942 differs from all other Leg 155 sites in that several units rich in biogenic carbonate were recovered, and overall Site 942 is characterized by a lower sedimentation rate. Six lithologic units were identified. Unit I is a heavily bioturbated Holocene calcareous clay with an iron-rich diagenetic crust at its base. Unit II is a late glacial mud interbedded with laminae of silt and very fine sand. It is subdivided into two subunits in a similar manner to Unit II of Site 932. Subunit IIA is a bioturbated mud with rare thin silt beds, and one sand bed that occurs at 14 mbsf. Subunit IIB mud contains thin to thick graded beds of fine sand to silt that increase in frequency and thickness toward the base of the unit. Units III and IV each contain a carbonate-rich interval underlain by a siliciclastic interval. Unit III consists of a thin bed of calcareous mud (IIIA) overlying a sequence of interbedded silt and sand (IIIB). Unit IV resembles Unit III, with more abundant sand. Unit V is a greenish gray calcareous clay. Unit VI is a gray mud with laminae and rare beds of silt. Carbonate Units I and V and Subunits IIIA and IVA represent intervals of relatively slow sedimentation rate during times of reduced terrigenous influx. The color banded and laminated silty clays of Unit VI are similar to the levee deposits of Site 932 and other Leg 155 sites, and suggest deposition from frequent over-bank flow of turbidity currents. The turbidites of Unit II and Subunits IIIB and IVB contain a higher proportion of sand than other Leg 155 sites, and may indicate a distinct source of sediment supply. Reworking of a transgressive sand sheet left over from the sea-level rise that culminated in calcareous Unit V has been hypothesized as a likely source (Flood, Piper, Klaus, et al., 1995). Primary age control for this site is also provided by the paleomagnetic Lake Mungo Excursion (30 ka) that was observed at 11-12 mbsf, and the $Y_{P \text {. obliquiloculata }}$ datum (40 ka) at 23 mbsf (Flood, Piper, Klaus, et al., 1995). A more detailed age model for this site is presented in Showers et al. (this volume). With the exception of one sample from Unit I, our data set is limited to sediments from the underlying siliciclastic units. 
A

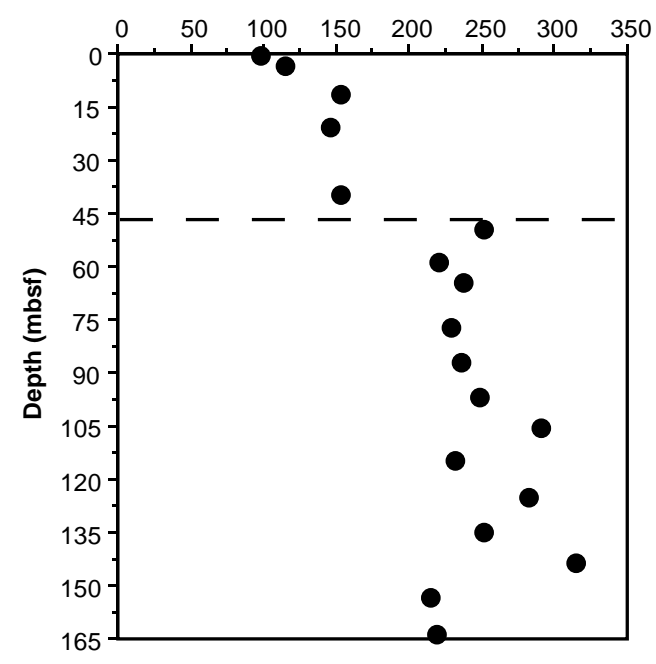

B

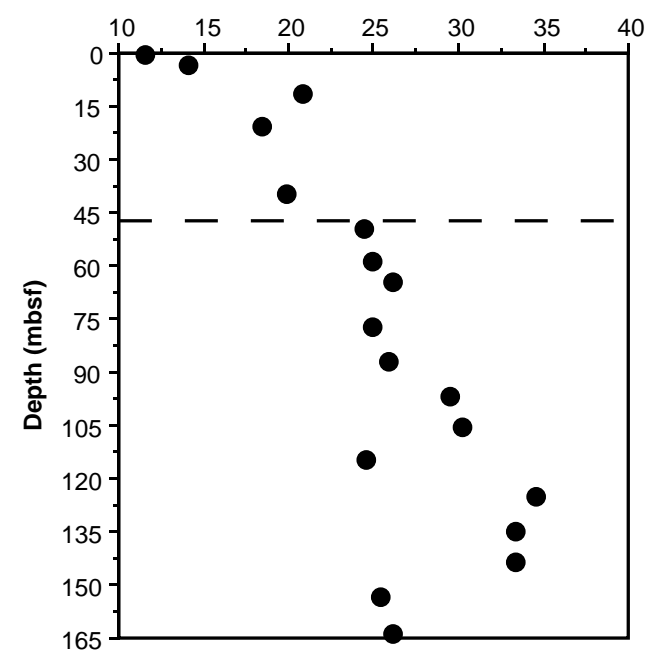

C

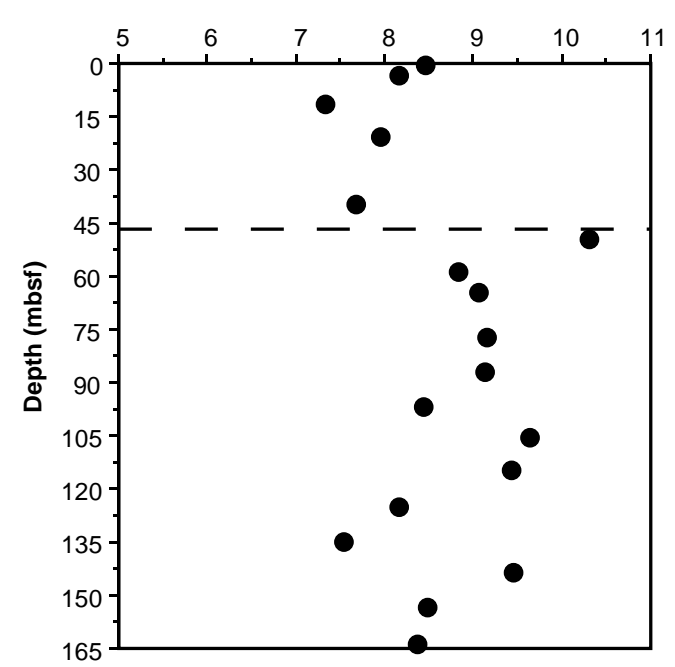

Figure 3. Depth profiles of elemental C:N:P ratios for Site 932. A. OC:OP vs. depth. B. TN:OP vs. depth. C. OC:TN vs. depth. Dashed line represents the boundary between the subunits identified in Figure 2.

\section{RESULTS}

Solid-phase P, OC, and TN data, and C:N:P elemental ratios for Holes 932A and 932B are given in Table 1. Depth profiles of solidphase $\mathrm{P}$ speciation and OC:OP, TN:OP, and OC:TN ratios are shown in Figures 2 and 3. The single sample from Hole 932B is plotted along with the data from Hole 932A. We justify this by noting the nearly identical lithologies of these two holes, and we have assumed that the strata correlate well enough to superimpose the two.

Solid-phase P, OC, and TN data, and C:N:P elemental ratios for Holes 942A and 942C are given in Table 2. Depth profiles of solidphase $\mathrm{P}$ speciation and $\mathrm{OC}: \mathrm{OP}, \mathrm{TN}: \mathrm{OP}$, and OC:TN ratios are shown in Figures 4 and 5. In the case of Hole 942C, only samples shallower than Section 155-942C-2H-4 from Hole 942C are plotted; reported depths for samples from Sections 155-942C-2H-4 and 5H-1 were offset from their likely correlatives in Hole 942A (Flood, Piper, Klaus, et al., 1995) and, therefore, are omitted.

\section{DISCUSSION}

Hole 932

\section{Sedimentary Phosphorus Distribution}

Total sedimentary P (Fig. 2) is dominated by IP. OP falls from a concentration of $5.05 \mu$ moles $/ \mathrm{g}$ at $3.57 \mathrm{mbsf}$ to $3.01 \mu \mathrm{moles} / \mathrm{g}$ at $163.63 \mathrm{mbsf}$, a drop of $40 \%$. The minimum OP concentration $(2.14$ $\mu$ mole/g) is at $143.45 \mathrm{mbsf}$, and represents a drop of $58 \%$ from the top interval. The observed downcore decrease in solid-phase OP is due in part to the mineralization of organic matter, as evidenced by the high concentration phosphate in pore waters (Fig. 6A) relative to typical bottom-water phosphate concentrations of 1 to $3 \mu \mathrm{M}$ (Millero and Sohn, 1991). The extent to which a secular trend of diminishing OP input to the sediments at this site is superimposed upon the mineralization-driven negative OP profile is difficult to ascertain. Other than this relatively monotonic drop, there is little structure in the OP profile.

The TP and IP profiles parallel each other because IP constitutes the bulk of the TP sedimentary reservoir (Fig. 2A). There are three notable features in the IP profile: (1) an IP concentration maximum centered at 11.54 mbsf (Subunit IIA); (2) an IP concentration minimum at 40.06 mbsf (Subunit IIA); and (3) a relatively constant IP concentration within Subunit IIB, with the exception of samples from 77.53 and 96.76 mbsf, which are enriched in IP relative to the constant background that characterizes Subunit IIB.

The maximum in TP and IP centered at 11.54 mbsf falls just above an interval (14-21 mbsf) characterized as one of unusually low density and high porosity, interpreted as resulting either from a higher sedimentation rate or the presence of gas bubbles (Flood, Piper, Klaus, et al., 1995). The higher IP concentrations observed in the $11.54-\mathrm{cm}$ horizon overlying this anomalous low-density interval are consistent with a reduction in a sedimentation rate above $14 \mathrm{mbsf}$, and the development of a diagenetic regime in which remineralized OP could be concentrated into secondary, inorganic IP phases. Although the resolution of Site 932 pore-water profiles is too coarse to pinpoint zones of diagenetic $\mathrm{P}$ concentration, a clear drop in porewater phosphate concentration is observed between 4.45 and 13.45 mbsf (Fig. 6A), indicating removal of phosphate from pore waters to the solid phase. The contrast between the downward decreasing porewater phosphate profile and the ammonia profile, which increases steadily with depth (Fig. 6B), supports the contention that phosphate is being removed diagenetically, since both phosphate and ammonia are released in roughly stoichiometric proportions during remineralization of organic matter (e.g., see Ruttenberg and Berner, 1993). If there was no diagenetic removal of phosphate to form secondary inorganic phosphate minerals, the pore-water phosphate and ammonia profiles should describe similar depth trends. The contribution of a 
A Solid-phase P ( $\mu$ mole/g)

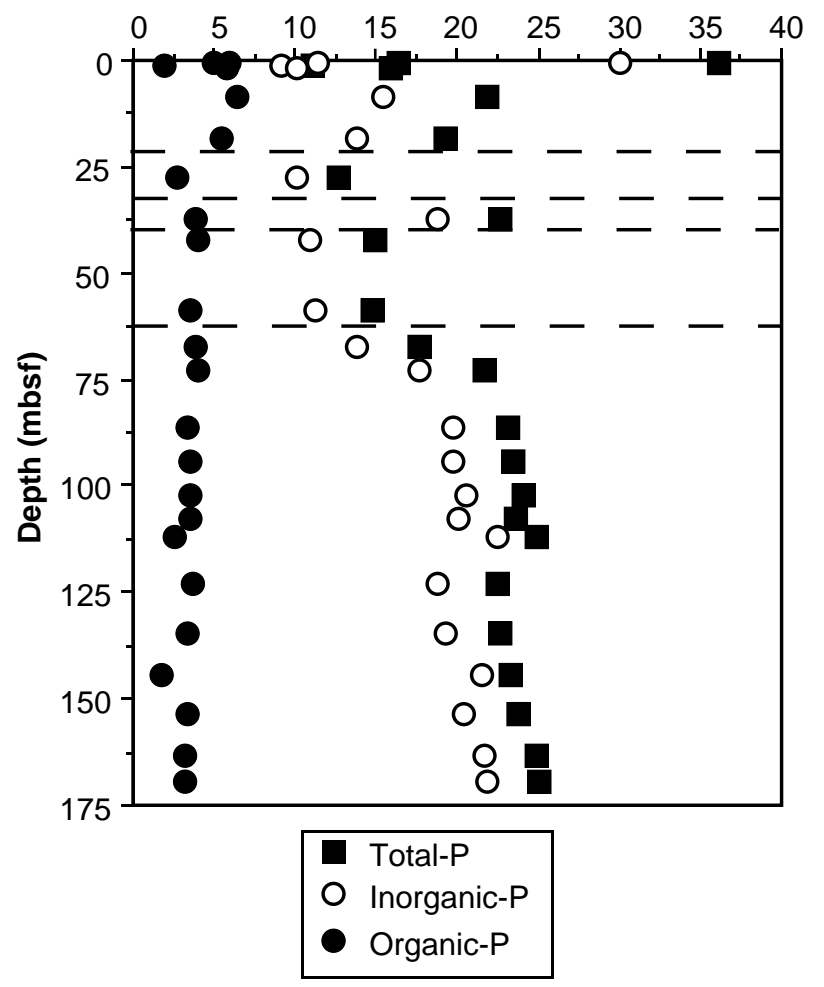

B

Fraction of Total-P

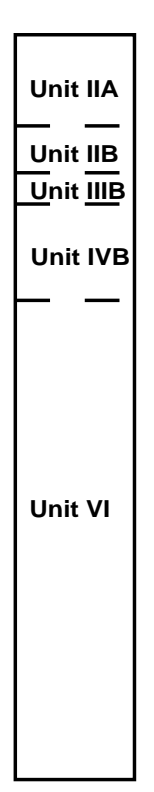

Figure 4. Depth profiles of solid-phase P distribution for Site 942. A. Concentration of TP, IP, and OP. B. Distribution of IP and OP expressed as the fraction of TP:IP/TP and OP/TP. Lithostratigraphic units are shown in the central panel, and unit boundaries are indicated by the dashed line.Although Unit I is not explicitly shown in the stratigraphic column shown between the two data panels, one sample from Unit I is plotted in this figure (see Table 2 for data).

different, more IP-enriched sediment source cannot be ruled out, however, as contributing to the higher IP content of the 11.54 and 21.05 mbsf horizons.

The minimum in TP and IP at 40.06 mbsf falls in an interval characterized as disturbed sediment, perhaps representing a debris flow. The debris-flow material consists of a deformed mud matrix with numerous mud clasts (Flood, Piper, Klaus, et al., 1995). The low IP concentration, similar to that of underlying Subunit IIB, suggests the possibility that older Subunit IIB sediment could have been a source for this debris.

The relatively constant concentrations in Subunit IIB reflect a more invariant supply of P-bearing sediment (as contrasted with the profile observed for Subunit IIA). The scatter observed is most likely owing to heterogeneities associated with interbedded silt/sand that is characteristic of this unit. The invariant pore-water phosphate concentrations observed throughout Subunit IIB (Fig. 6A) imply that mineralization of OP and the formation of secondary, authigenic IP phases is minimal to absent.

In the absence of more detailed solid-phase $\mathrm{P}$ speciation data, it is not possible to discern or quantify the extent to which the remineralized OP is sequestered in secondary authigenic phosphatic minerals. Plots of IP/TP and OP/TP vs. depth (Fig. 2B) suggest that such diagenetic transformations may occur in the upper $100 \mathrm{~m}$ of sediment. This is consistent with observations of $\mathrm{P}$ diagenesis in other continental margin environments (Ruttenberg and Berner, 1993; Louchouarn et al., in press). The decoupled phosphate and ammonium pore-water profiles for this site, as described above, are also consistent with the argument for the diagenetic transformation of OP to IP. The coincident drop of pore-water phosphate and pore-water iron in the upper $23 \mathrm{~m}$ at this site (Fig. 6A), and the observation of diagenetic vivianite (an authigenic ferrous phosphate mineral) as a widespread accessory mineral in Site 932 sediments (Flood, Piper, Klaus, et al., 1995), rais- es the possibility that diagenetic vivianite is forming in the upper 23 $\mathrm{m}$ at this site.

\section{Elemental C:N:P Ratios}

Depth profiles of elemental ratios are shown in Figure 3. Profiles of OC:OP and TN:OP ratios are very similar (Fig. 3A, B). Both show a trend of an increasingly OP-impoverished organic matter pool with depth. Ratios in Subunit IIA are distinctly lower than those in Subunit IIB. OC:TN ratios also fall into two populations, with lower OC:TN ratios in Subunit IIA relative to Subunit IIB, but there is significantly more scatter, and the trend of increasingly higher ratios with depth within each unit is not as evident (Fig. 3C).

In Subunit IIA, lower OC:OP and TN:OP ratios can be interpreted as reflecting a greater proportion of marine organic matter. In contrast, the ratios observed in Subunit IIB are significantly more impoverished in OP, which is consistent with the presence of a more important terrigenous organic matter component. The more "terrestriallooking" organic matter in Subunit IIB, as revealed by the elemental ratios, is consistent with the greater abundance of silt/s and interbeds that reflect deposition by turbidity currents of coarser material of terrigenous origin. The more "marine-looking" organic matter in Subunit IIA, again, as revealed by the elemental ratios, is consistent with the description of this unit as representing hemipelagic deposition after the channel became inactive, with silt/sand laminae less abundant. The fact that the OC:TN depth profile does not display as clear an increase as the OC:OP and TN:OP profiles may be due to the fact that the quantity TN may include inorganic as well as organic nitrogen. Studies monitoring progressive changes in OC:TN ratios as a function of extent of mineralization have shown that after an initial drop, these ratios can increase because of incorporation of inorganic $\mathrm{N}$ into the detrital matrix (Rice and Tenore, 1981; Rice, 1982). 


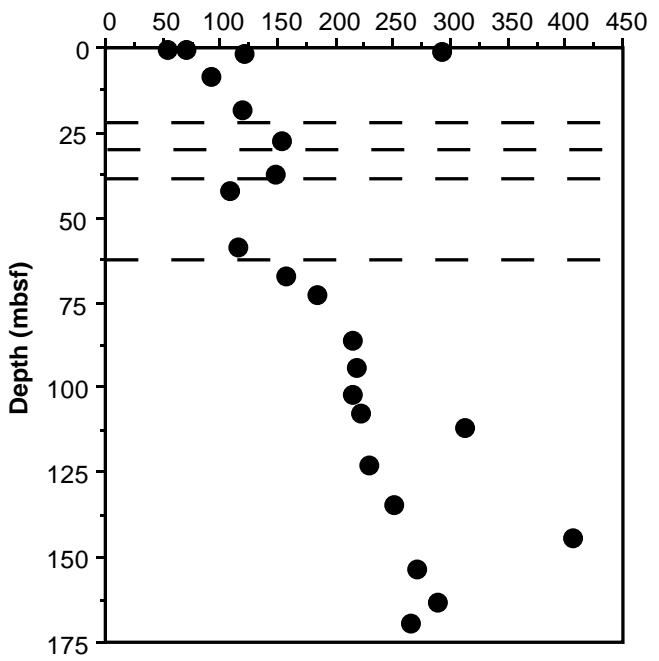

B

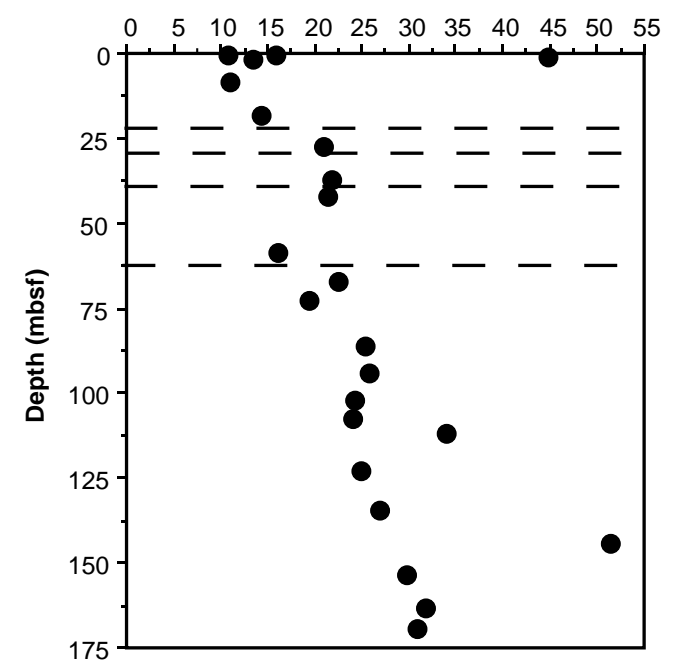

C

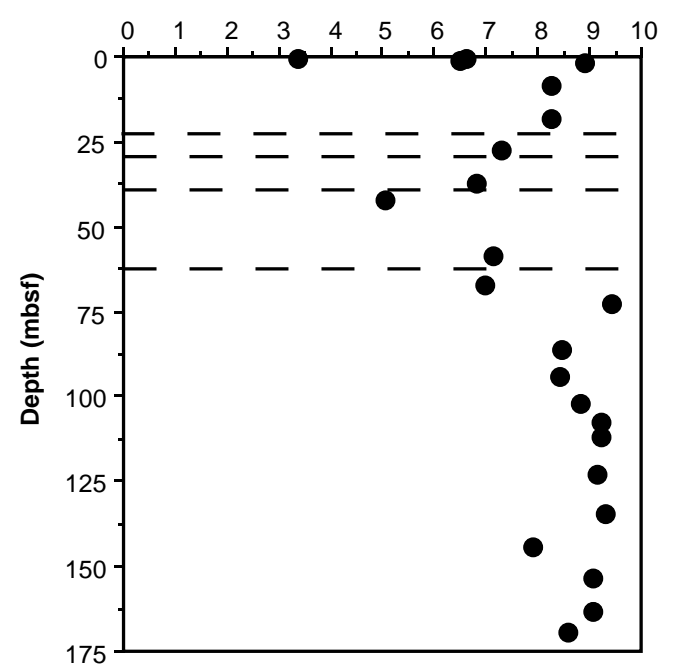

Figure 5. Depth profiles of elemental C:N:P ratios for Site 942. A. OC:OP vs. depth. B. TN:OP vs. depth. C. OC:TN vs. depth. Dashed lines represent the boundaries between the subunits identified in Figure 4.
Hole 942

Sedimentary Phosphorus Distribution

Total sedimentary P (Fig. 4) is dominated by IP in Site 942, as is the case for Site 932. The TP and IP profiles again parallel each other because IP constitutes the bulk of the TP sedimentary reservoir. Overall, profiles are much noisier at this site than at Site 932, in part due to the absence of data from the calcareous layers that intercalate between siliciclastic Subunits IIB, IIIB, IVB, and Unit VI. We note that due to sparse sample coverage within Subunits IIB, IIIB, and IVB, the trends described may not be representative of the entire subunit.

The single sample analyzed from Unit I had a lower $\mathrm{P}$ content than the first interval of underlying Subunit IIA (Table 2; Fig. 4A). The P content of samples in Subunit IIA is highly variable, containing both the highest and the lowest $\mathrm{P}$ concentrations observed in the entire profile. The highly variable $\mathrm{P}$ content within this subunit may be the result of the interbedded sand/silt layers in Subunit IIA mud. This subunit has a significantly higher OP content than the underlying units.

The sample from Subunit IIB has a relatively low $\mathrm{P}$ content that may be the result of the frequent sandy layers reported for this unit (sand beds locally form $\approx 50 \%$ of core sections), but it is difficult to confirm this based on a single sample. Subunit IIIB is inferred to have a relatively low sedimentation rate based on the higher prevalence of burrows at this site relative to other Leg 155 levee sites (Flood, Piper, Klaus, et al., 1995, p. 548). The relatively high P content of the Subunit IIIB sample may be the result of diagenetic concentration processes in this slowly accumulating interval, in a manner similar to that described for the IP maximum in the Site 932 depth profile. As is the case for Site 932, the argument for secondary concentration of IP in Site 942 sediments is supported by the decoupled profiles of pore-water phosphate and ammonium at this site (Fig. 7), which indicate that phosphate released to pore water during diagenetic organic matter remineralization is removed from pore water to the solid phase, whereas no such removal process is operating on ammonium. This is a classic pattern observed during diagenesis, and is interpreted to reflect the removal of phosphate into secondary authigenic phosphate minerals (e.g., Ruttenberg and Berner 1993; Louchouarn et al., in press). The two samples from Subunit IVB are slightly enriched above the Subunit IIB sample, and are quite similar in their P distribution. This is consistent with the description of this unit as highly burrowed, which would tend to vertically homogenize the sediment.

Unit VI has significantly greater sample coverage, and is the only unit to show smoothly varying profiles in P distribution (Fig. 4A). This unit is described as being composed of fairly homogeneous silty turbidites (Flood, Piper, Klaus, et al., 1995), which may account for the smoother depth trends observed. Immediately below the upper boundary of Unit VI, IP content increases significantly from 13.84 $\mu$ moles P/g at $67.45 \mathrm{mbsf}$ to $19.74 \mu$ moles P/g at $86.55 \mathrm{mbsf}$ (an increase of $43 \%$ ), below which it remains relatively constant. The increase in IP immediately below the boundary with Subunit IVB is not accompanied by a discernible drop in OP. This rules out diagenetic redistribution from OP to IP within Unit VI, and instead implies a change in the input flux at this boundary, with a larger flux of IP to Site 942 during most of the time represented by Unit VI, diminishing during the latter phase of Unit VI deposition. This change in IP input could result from a higher overall sediment flux; a change in sediment supply from a more IP-enriched source during Unit VI to a source less IP-enriched; or both of the above, at the Unit VI/Subunit IVB transition. A change in sediment source at this boundary has been inferred on the basis of lithostratigraphic evidence. The higher sand content of turbidites in Unit II and Subunits IIB and IVB distinguishes them from other Leg 155 turbidites, implying a distinct sediment source, whereas those in Unit VI are similar to other Leg 155 turbidites, implying the same provenance as Leg 155 turbidites from other sites (Flood, Piper, Klaus, et al., 1995). The P distribution data is consistent with the existence of two distinct sources of sediment. 
A

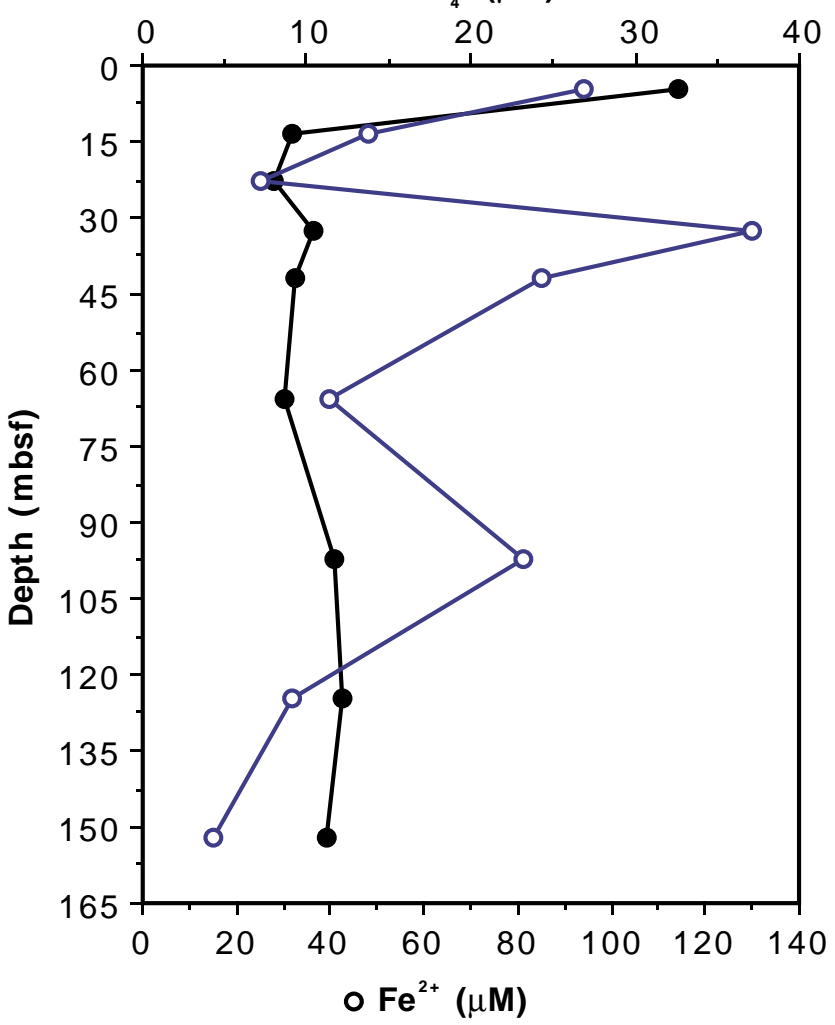

B

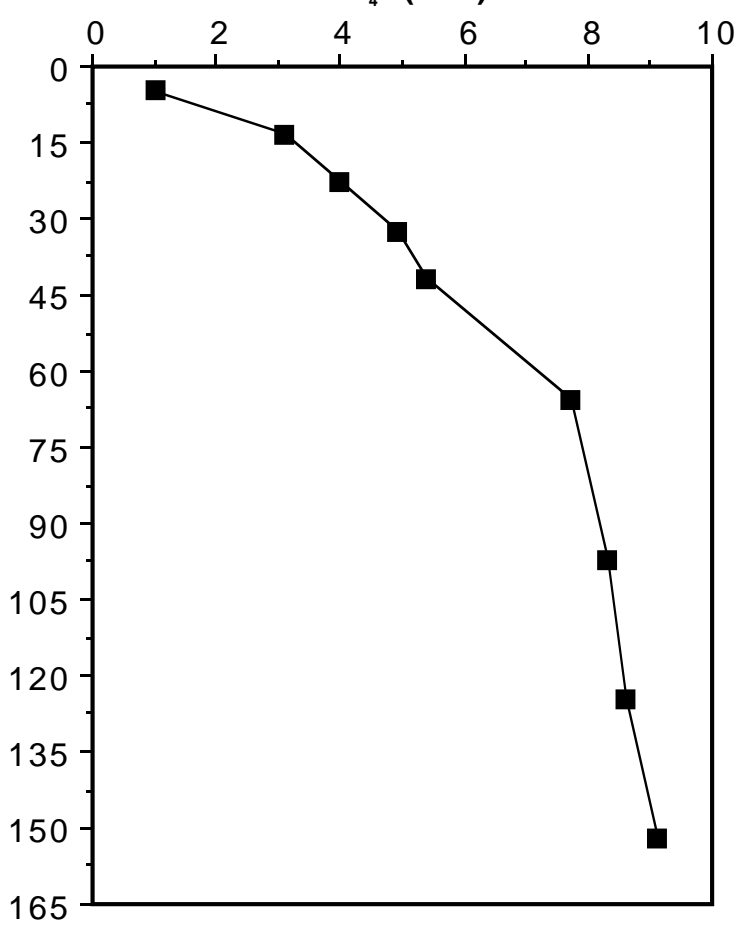

Figure 6. Site 932 pore-water data from Flood, Piper, Klaus, et al. (1995). A. Phosphate $(\mu \mathrm{M})$ and ferrous iron $(\mu \mathrm{M})$. B. Ammonium (mM).
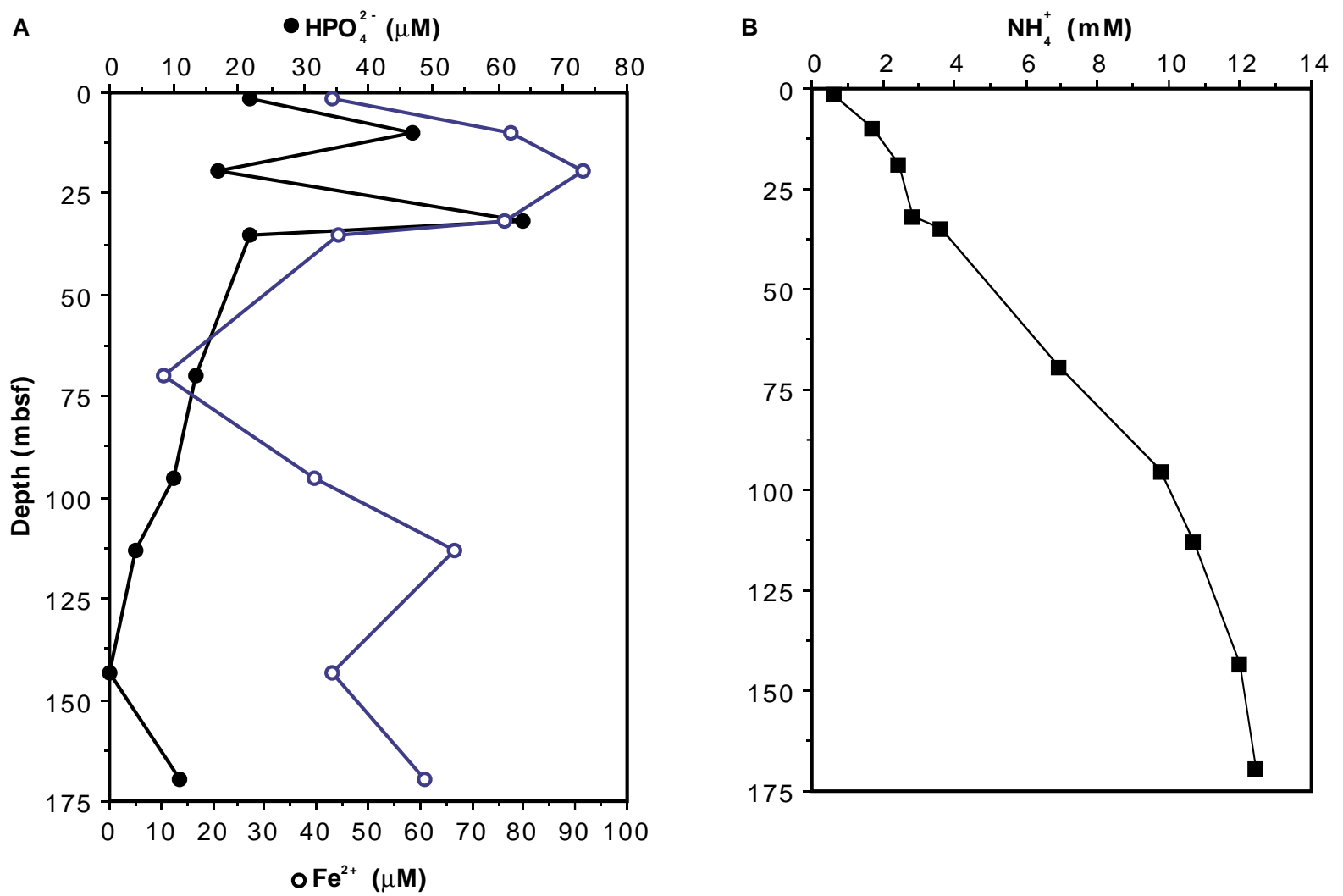

Figure 7. Site 942 pore-water data from Flood, Piper, Klaus, et al. (1995). A. Phosphate $(\mu \mathrm{M})$ and ferrous iron $(\mu \mathrm{M})$. B. Ammonium (mM). 
As is the case for Site 932, plots of IP/TP and OP/TP vs. depth for Site 942 (Fig. 4B) suggest that diagenetic transformations, whereby remineralized OP is sequestered in secondary authigenic phosphatic minerals, may occur in the upper $80 \mathrm{~m}$ of sediment. In the absence of more detailed solid-phase $\mathrm{P}$ speciation data, it is not possible to confirm or quantify this process; however, it is consistent with observations of $\mathrm{P}$ diagenesis in other continental margin environments (Ruttenberg and Berner, 1993; Louchouarn et al., in press), and also with the pore-water profiles of phosphate, ammonium, and iron (Fig. 7), which are similar to those of Site 932 (Fig. 6). In contrast to Site 932, however, where the maximum in pore-water phosphate occurred within the first depth interval and decreased steadily below this horizon, the phosphate profile in sediments from Site 942 displays a subsurface maximum between 1.45 and 35.25 mbsf. Although fairly noisy, this is the classic profile observed in situations of authigenic phosphate mineral formation. The initial buildup in pore-water phosphate is largely due to organic matter remineralization, and the reversal to a negative, downward decreasing gradient is interpreted as reflecting removal of phosphate to the solid phase (Berner 1980). The low resolution of the pore-water data makes it impossible to ascertain the depths at which authigenic phosphate mineral formation is occurring, and whether there are multiple horizons of authigenesis. The pore-water iron profile also displays a subsurface maximum which is coincident with that in phosphate, again suggesting that authigenic vivianite may be forming. This interpretation is supported by the presence of diagenetic vivianite, confirmed by X-ray diffraction (XRD) analysis, in Site 942 sediments (Flood, Piper, Klaus, et al., 1995, p. 545).

\section{Elemental C:N:P Ratios}

Depth profiles of elemental ratios for Site 942 are shown in Figure 5. Profiles of OC:OP and TN:OP ratios look very similar (Fig. 5A, B), and display an apparent trend of an increasingly OP-impoverished organic matter pool with depth. The paucity of sample coverage in Units II-IV make it impossible to identify trends within these units. The OC:OP and TN:OP ratios in Unit VI, however, show a distinctly progressive trend of increasingly higher ratios with depth. As is the case in Site 932 sediments, the ratios fall into two distinct populations, with ratios in Units I-IV distinctly lower than those in Unit VI. With the exception of one sample in Subunit IIA (155-942-1H-1, $98-103 \mathrm{~cm}, 0.98 \mathrm{mbsf}$ ), it is evident that ratios in Units I-IV look more "marine" than do ratios in the lower part of Unit VI. In contrast, the ratios observed in Unit VI trend from values very similar to the overlying units ("marine-like") to values significantly more impoverished in OP. This is consistent with an increasingly important terrigenous organic matter component in deeper intervals of Unit VI. There is no systematic depth trend in OC:TN ratios, except that ratios in Unit VI are higher and more uniform than ratios in the overlying units.

The more "terrestrial-looking" organic matter in Unit VI, as revealed by the elemental ratios, is consistent with the abundant silty turbidites in this unit, which imply a detrital terrigenous source. The more "marine-looking" organic matter in the overlying units, as revealed by the elemental ratios, implies a lower detrital terrigenous input, giving way to a greater proportion of marine organic matter from hemipelagic deposition.

\section{Reconciling Elemental Ratios with Other Indicators of Organic Matter Source}

In the previous sections, we observed that trends in elemental $\mathrm{C}: \mathrm{N}: \mathrm{P}$ ratios can be interpreted in terms of sedimentary organic matter comprised of variable mixtures of terrestrial and marine organic matter. Stable carbon isotopes provide a more common tool for distinguishing different sources of organic matter to marine sediments (e.g., see Goñi, this volume). Terrestrial C-3 plants are typically depleted in ${ }^{13} \mathrm{C}$, and are characterized by $\delta^{13} \mathrm{C}$ ranging from $-23 \%$ o to $-34 \%$. Marine plankton are enriched relative to $\mathrm{C}-3$ terrestrial plants, with $\delta^{13} \mathrm{C}$ ranging from $-18 \%$ o to $-24 \%$ o. On the basis of this difference, the $\delta^{13} \mathrm{C}$ signature of bulk organic matter has been used to distinguish terrestrial from marine organic sources (Fry and Sherr, 1984).

We next investigate the extent to which the source identification predicted on the basis of elemental ratios is consistent with that yielded by the carbon isotopic signature of bulk TOC from Sites 932 and 942. Figure 8 illustrates the correlation between $\delta^{13} \mathrm{C}_{\mathrm{TOC}}$ for these sediments and the three elemental ratios discussed in the previous sections: OC:OP, OC:TN, and TN:OP. All three plots for both cores show systematic relationships consistent with sediments composed of a mixture of terrestrial and marine organic matter. The clearest example of this relationship is observed for the correlation between $\delta^{13} \mathrm{C}_{\mathrm{TOC}}$ and OC:OP ratios (Fig. 8A, D). The hyperbolic trend observed is characteristic of the mixing line obtained between two endmembers in ratio-to-ratio plots. Sediments with low OC:OP ratios, characteristic of more P-enriched marine organic matter, display the heaviest $\delta^{13} \mathrm{C}_{\mathrm{TOC}}$ values, which is consistent with the isotopic signature of marine organic matter. At the other end of the trend, samples with high OC:OP ratios are characterized by lighter $\delta^{13} \mathrm{C}_{\mathrm{TOC}}$ values, both traits of terrestrially derived, vascular plant debris.

For Site 932, the isotopically heavier samples characterized by lower ratios derive from Subunit IIA, and these coupled parameters indicate an organic matter pool with a significant marine-derived component (Figs. 3, 8A). The isotopically lighter samples with higher ratios derive from Subunit IIB and indicate an organic matter pool dominated by terrestrially derived organic matter. This is consistent with conclusions drawn about the nature of organic matter source to these sediments derived from data on lignin break-down products (Goñi, this volume).

For Site 942, most samples from Unit I through Subunit IVB are characterized by low elemental ratios and heavy carbon isotopic signatures, consistent with a dominant marine organic matter component. Unit VI displays a range of elemental ratios and isotopic signatures from marine-like values near the boundary with Subunit IVB, to increasingly terrestrial-like values with an increasing depth below this boundary (Figs. 5, 8D). This shift from a more marine to a more terrestrial source of sedimentary organic matter is consistent with lithostratigraphic evidence for a transition from active levee deposition dominated by turbidite flows, which characterize the deeper intervals at these sites, giving way to a more hemipelagic sedimentation regime with reduced terrigenous input (Flood, Piper, Klaus, et al., 1995).

We note that at Site 942, the sample from the calcareous ooze is extremely enriched in OP and TN relative to OC (Table 2; Fig. 5), which is consistent with the virtual absence of a terrestrially derived organic matter component. Other intervals within the siliciclastic units of Site 942 with similarly low ratios occur near the boundaries with other calcareous ooze units and are, therefore, consistent with the cessation of terrigenous input during these intervals of increased biogenic carbonate sedimentation. Elemental ratios at Site 932 do not drop to the low values seen in some intervals from Site 942. This reflects the fact that no samples from calcareous intervals from Site 932 were analyzed in this study, and that all samples from the Site 932 siliciclastic units had appreciably more terrestrially derived organic matter relative to marine-derived organic matter. This contrast is also consistent with the overall lower sediment accumulation rates characteristic of Site 942 compared with Site 932.

Correlation of Oxygen Isotope Stratigraphy and Sea-Level Change with Shifts in C:N:P Ratios and $\delta^{13} C$ of Organic Matter in Sediments from Sites 932 and 942

Oxygen isotope stratigraphy derived from planktonic foraminifers from Sites 932 (Maslin et al., this volume) and 942 (Showers et 
A.

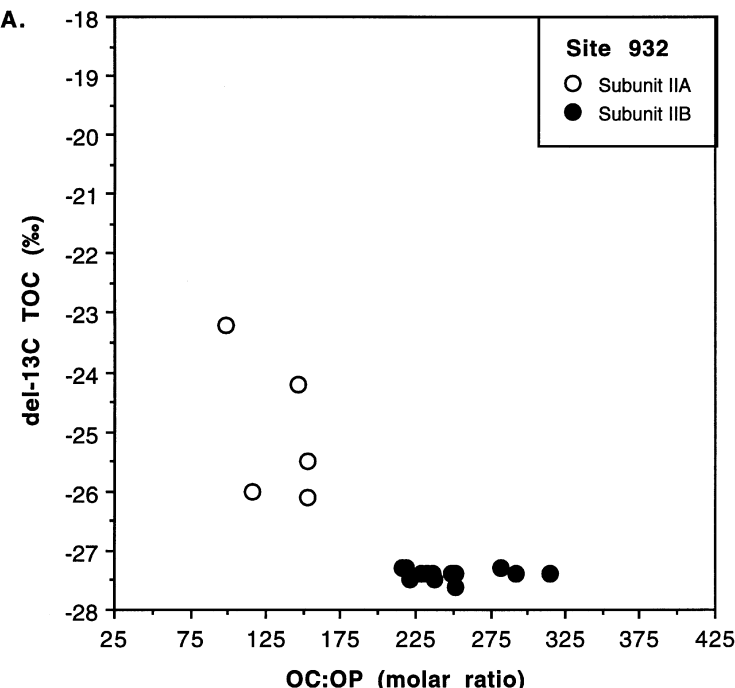

B.

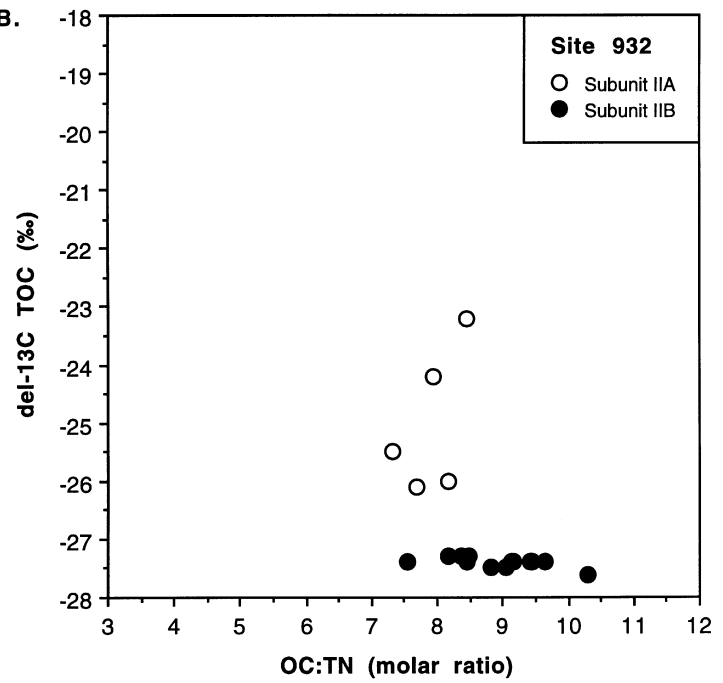

C.

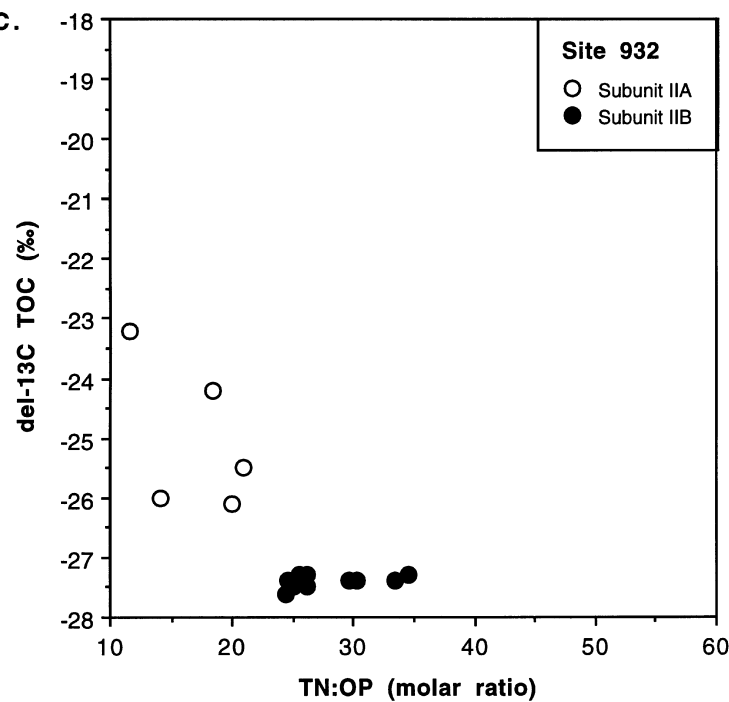

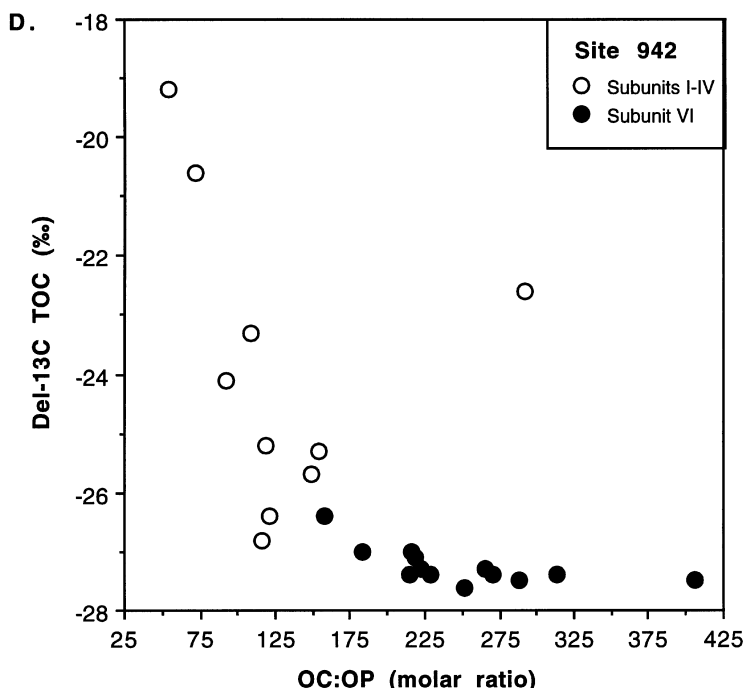
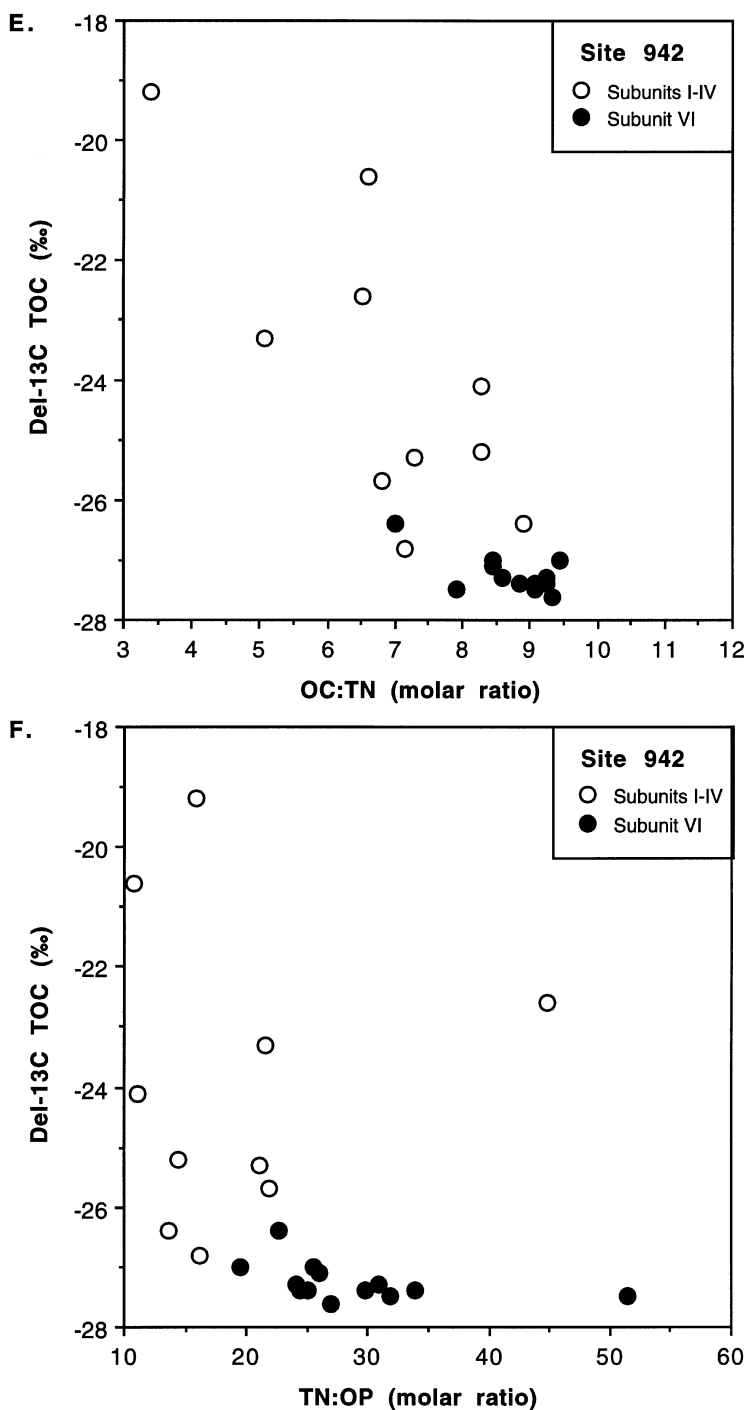

Figure 8. Correlation of the carbon isotopic composition of organic matter and elemental ratios. Site 932 : A. OC:OP vs. $\delta^{13} \mathrm{C}_{\mathrm{TOC}} \cdot \mathbf{B} . \mathrm{OC}: \mathrm{TN}$ vs. $\delta^{13} \mathrm{C}_{\mathrm{TOC}} \cdot \mathbf{C}$.

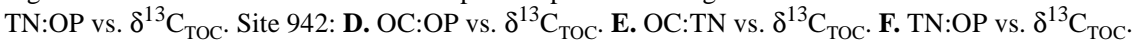


al., this volume) are shown in Fig. 9. Ages assigned to the boundaries between stratigraphic units are from age models constructed for Site 932 (Maslin et al., this volume), and for Site 942 (Showers et al., this volume). In cases where ages were not assigned to the specific depths of the unit boundaries, the age of the boundary has been extrapolated from the nearest depths that have age assignments. The depth scales of these plots are identical to earlier plots of phosphorus distribution and $\mathrm{C}: \mathrm{N}: \mathrm{P}$ ratios, to facilitate comparison of these data with the oxygen isotope stratigraphy.

Interpreting oxygen isotopic records recovered from Amazon Fan sediments is difficult due to the high rates of accumulation of terrigenous detritus, which result in low numbers of foraminifers in a given sample, and to the effects of turbidites and general reworking. This is clearly seen in the record for Site 932 (Fig. 9A). Age control points were assigned based on magnetic criteria (e.g., the Lake Mungo Excursion), biostratigraphic criteria (e.g., the $\mathrm{Y}_{P \text {. obliquiloculata }}$ datum), as well as several AMS ${ }^{14} \mathrm{C}$ dated intervals (Maslin et al., this volume). Oxygen isotopic trends that show clear evidence of changes in sea level are not evident at this site. Despite the lack of a clear visual trend in $\delta^{18} \mathrm{O}$, the age model of Maslin et al. (this volume) permits these and other data to be viewed within the context of the timing of oxygen isotope stages and associated changes in sea level. The age model of Maslin et al. (this volume) places the upper and lower boundaries of Subunit IIA at 8 and 68 ka, respectively, which encompasses all of isotopic Stages 2 and 3, and part of Stages 1 and 4 (see fig. 7, Flood et al., 1995, for the timing of oxygen isotopic stages and coincident eustatic variations in sea level). The more hemipelagic sediment of Subunit IIA, as inferred from the low C:N:P ratios and heavy $\delta^{13} \mathrm{C}_{\mathrm{TOC}}$ signatures of the organic matter in this interval (Figs. $3,8 \mathrm{~A}-\mathrm{C}$ ) implies that sedimentation of marine organic matter during times of high sea-level stand must have been relatively important. Subunit IIB, bounded at 68 and $75 \mathrm{ka}$ (Maslin et al., this volume), coincides with part of Stage 3 and the entire Stage 4, time intervals characterized by periods of moderate to low sea level. This is consistent with the higher proportion of terrigenous material in this subunit, as inferred from the higher $\mathrm{C}: \mathrm{N}: \mathrm{P}$ ratios and lighter $\delta^{13} \mathrm{C}_{\mathrm{TOC}}$ signatures of the organic matter in this interval, relative to Subunit IIA (Figs. 3, $8 \mathrm{~A}-\mathrm{C})$.

In contrast to Site 932 , a clear visual trend in $\delta^{18} \mathrm{O}$ of planktonic foraminifers is seen in Site 942 sediments (Fig. 9B), due to the presence of multiple layers rich in carbonate and lower sedimentation rate at Site 942. The most striking feature is the sharp excursion from values lighter than $-1.0 \%$ in Subunit IVB, to values exceeding $+0.5 \%$ in Unit VI. This excursion is coincident with the division between relatively high $\mathrm{C}: \mathrm{N}: \mathrm{P}$ ratios and light $\delta^{13} \mathrm{C}_{\mathrm{TOC}}$ in Unit VI, and lower $\mathrm{C}: \mathrm{N}: \mathrm{P}$ ratios and heavier $\delta^{13} \mathrm{C}_{\mathrm{TOC}}$ signatures in Units I-IV (Figs. 5, 8D-F), which is interpreted as resulting from a shift from input of more terrestrial organic matter during Unit VI to more hemipelagic sedimentation during earlier Units (I-IV). The age model of Showers et al. (this volume) places Unit VI in isotope Stage 6, a time of extreme sea-level lowstand, and Subunit IIB-Unit IV span isotope Stages 3-5, times of moderate to high sea level (see fig. 7, Flood et al., 1995). These inferred shifts in sea level are consistent with the changes in organic matter source just described, with Amazon River derived terrigenous material delivered to this site during the sea-level lowstand of Unit VI, giving way to a more important hemipelagic sedimentation in periods of moderate to high sea level, during which time the sediment of Units II-IV were deposited.

\section{SUMMARY AND CONCLUSIONS}

Phosphorus concentration and the relative distribution of organic vs. inorganic phosphorus (OP vs. IP) in sediments from Amazon Fan Sites 932 and 942 display depth variations consistent with interpretations of sediment accumulation history that have been proposed on the basis of lithostratigraphic features alone. In some instances, where lithostratigraphic data are ambiguous, the solid-phase P depth profiles provide information that supports one interpretation over others.

Depth trends in elemental OC:OP, OC:TN, and TN:OP ratios are consistent with a system that alternates between deposition of sediment dominated by terrestrial and marine organic matter. This is in line with what is known about Amazon Fan depositional history; that it is supplied with terrigenous detritus during glacial sea-level lowstands, but receives dominantly marine-derived sediment during highstands of sea level, when most Amazon River sediment is trapped on the shelf. The absolute profile shapes of these elemental ratios are consistent with shifts in organic matter source from dominantly terrestrial to dominantly marine sources predicted on the basis of both lithostratigraphic and other organic geochemical (e.g., lignin break-down product) data. The absolute timing of these shifts, from dominantly terrestrial to dominantly marine organic matter deposition, is consistent with changes in sea level predicted on the basis of age models developed from oxygen isotope stratigraphy and paleomagnetic data.

At both Sites 932 and 942, sequestering of remineralized organic $\mathrm{P}$ by secondary authigenic phosphate minerals is suggested by OP vs. IP profiles. Decoupled phosphate and ammonium pore-water profiles at both sites are consistent with this interpretation, but confirmation and quantification of this process will require a more detailed $\mathrm{P}$-speciation study. The coincidence of a draw-down in both pore-water phosphate and pore-water iron at these sites suggests that diagenetic vivianite may be an important authigenic phosphate mineral in these sediments. The presence of vivianite at both sites has been confirmed by XRD analysis.

The successful use of elemental C:N:P ratios as indicators of organic matter source is bolstered by the systematic correlation between these ratios and the carbon isotopic signature of TOC observed at both sites. OC:OP ratios appear superior to OC:TN ratios in identifying shifts in organic matter source, which may result from the fact that significant inorganic nitrogen may be included in the measured quantity TN, which will perturb the OC:TN ratio from that of pure organic matter. The clear distinction in $\mathrm{C}: \mathrm{N}: \mathrm{P}$ ratios of organic matter between sediments dominated by terrestrial vs. hemipelagic sedimentation, and the tight correlation between these ratios and the $\delta^{13} \mathrm{C}_{\mathrm{TOC}}$ signature, suggest that documented diagenesis in these sediments appears not to obscure the trends which indicate shifts in organic matter source to these sediments.

\section{ACKNOWLEDGMENTS}

Mark Maslin and Bill Showers generously provided oxygen isotope and age model data for Sites 932 and 942, respectively. We acknowledge Ian Jarvis and Craig Glenn for thorough and constructive reviews, and Adam Klaus for assistance during the final stages of manuscript preparation. KCR wishes to acknowledge Co-chief scientists David Piper and Roger Flood for their willingness to broaden the initial focus of the stated goals of Leg 155 to include a study of phosphorus geochemistry. Eileen Monaghan and So Yung Morris provided assistance in the laboratory. This work was supported by NSF grants USSP-26090400 and EAR-80658500 awarded to KCR.

\section{REFERENCES}

Aspila, K.I., Agemian, H., and Chau, A.S.Y., 1976. A semi-automated method for the determination of inorganic, organic and total phosphate in sediments. Analyst, 101:187-197.

Berner, R.A., 1980. Early Diagenesis: A Theoretical Approach: Princeton, NJ (Princeton Univ. Press).

Black, C.A., 1965. Methods of Soil Analysis, (Part II): Madison, WI (Amer. Soc. Agron. Inc. Publ.). 
Damuth, J.E., Flood, R.D., Knowsmann, R.O., Belderson, R.H., Gorini, M.A., 1988. Anatomy and growth patterns of Amazon deep-sea fan as revealed by long-range side-scan sonar (GLORIA) and high-resolution seismic studies. AAPG Bull., 72:885-911.

Flood, R.D., Piper, D.J.W., and Shipboard Scientific Party, 1995. Introduction. In Flood, R.D., Piper, D.J.W., Klaus, A., et al., Proc. ODP, Init. Repts., 155: College Station, TX (Ocean Drilling Program), 5-16.

Flood, R.D., Piper, D.J.W., Klaus, A., et al., 1995. Proc. ODP, Init. Repts., 155: College Station, TX (Ocean Drilling Program).

Fry, B., and Sherr, E.B., 1984. $\delta^{13} \mathrm{C}$ measurements as indicators of carbon flow in marine and freshwater ecosystems. Contrib. Mar. Sci., 27:13-47.

Likens, G.E., Bormann, F.H., and Johnson, N.M., 1981. Interaction between major biogeochemical cycles in terrestrial ecosystems. In Likens, G.E., (Ed.), Some Perspectives of the Major Biogeochemical Cycles-SCOPE 17: New York (Wiley), 93-112.

Louchouarn, P., Lucotte, M., Duchemin, E., and de Vernal, A., in press. Early diagenetic processes in recent sediments of the Gulf of St. Lawrence: phosphorus, carbon, and iron burial rates. Mar. Geol.

Mach, D.M., Ramirez, A., and Holland, H.D., 1987. Organic phosphorus and carbon in marine sediments. Am. J. Sci., 278:429-441.

Manley, P.L., and Flood, R.D., 1988. Cyclic sediment deposition within the Amazon deep-sea fan. AAPG Bull., 72:912-925.

Millero, F. and Sohn, M., 1991. Micronutrients in the Ocean. In Chemical Oceanography: New Jersey (Telford Press), 323-352.

Nittrouer, C.A., DeMaster, D.J., Figueiredo, A.G., and Rine, J.M., 1991. AmasSeds: An interdisciplinary investigation of a complex coastal environment. Oceanography, 4:3-7.
Ostermann, D.R., Karbott, D., and Curry, W.B., 1990. Automated system to measure the carbonate concentration of sediments. WHOI Tech. Rep., 90103.

Redfield, A.C., Ketchum, B.H., and Richards, F.A., 1963. The influence of organisms on the composition of seawater. In Hill, M.N. (Ed.), The Sea. (Vol. 2): New York (Wiley), 26-77.

Rice, D.L., 1982. The detritus nitrogen problem: New observations and perspectives from organic geochemistry. Mar. Ecol.: Progr. Ser., 9:153-162.

Rice, D.L. and Tenore, K.R., 1981. Dynamics of carbon and nitrogen during the decomposition of detritus derived from estuarine macrophytes. Estuarine Coastal Shelf Sci., 13:681-690.

Ruttenberg, K.C., 1992. Development of a sequential extraction technique for different forms of phosphorus in marine sediments. Limnol. Oceanogr., 37:1460-1482.

1993. Reassessment of the oceanic residence time of phosphorus. Chem. Geol., 10: 405-409.

Ruttenberg, K.C., and Berner, R.A., 1993. Authigenic apatite formation and burial in sediments from non-upwelling, continental margin environments. Geochim. Cosmochim. Acta., 57:991-1007.

Strickland, J.D.H., and Parsons, T.R., 1972. A Practical Handbook of Seawater Analysis: Ottawa (Fisheries Research Board of Canada).

Date of initial receipt: 4 January 1996

Date of acceptance: 31 May 1996

Ms 155SR-241 
A

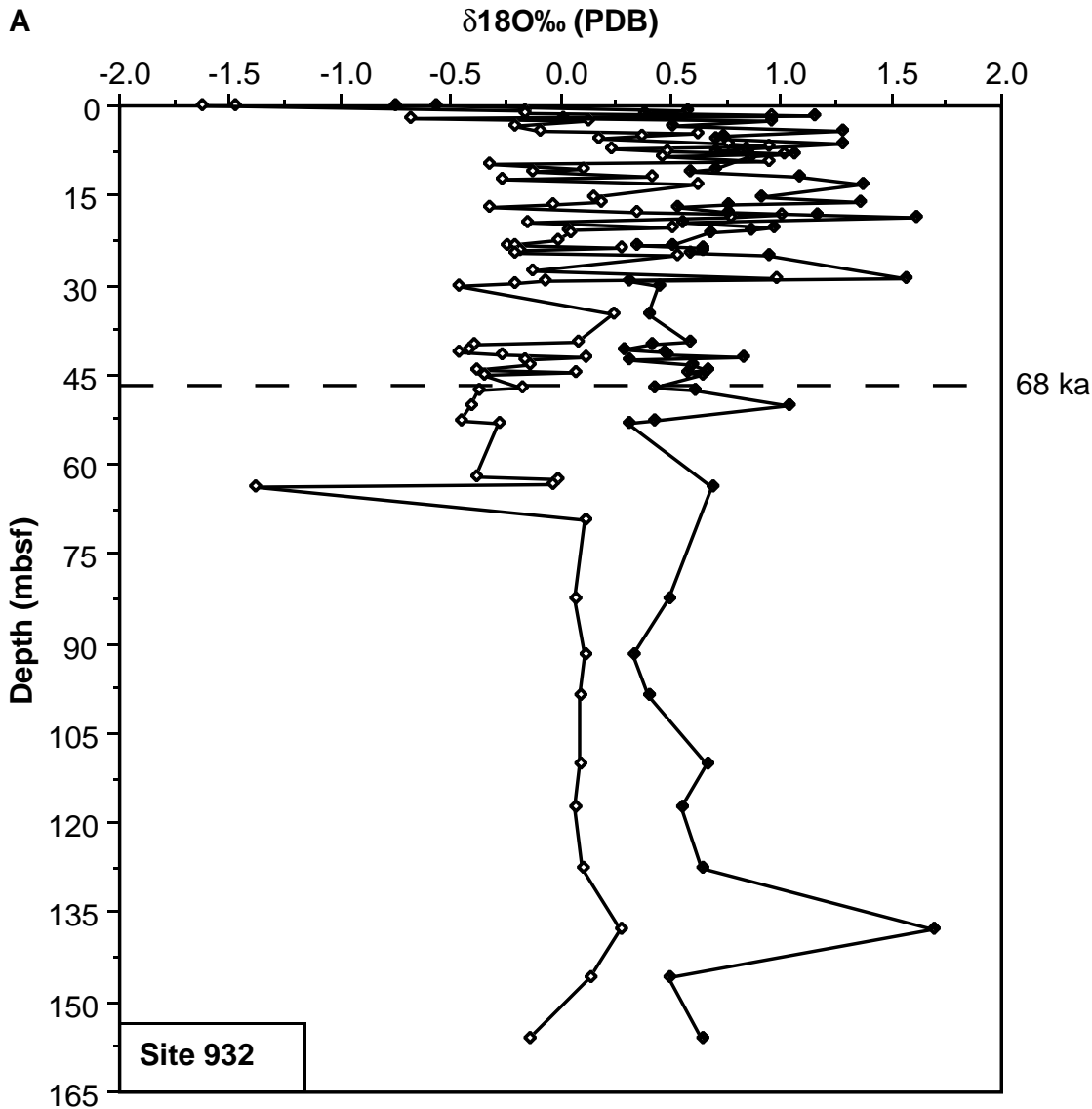

B

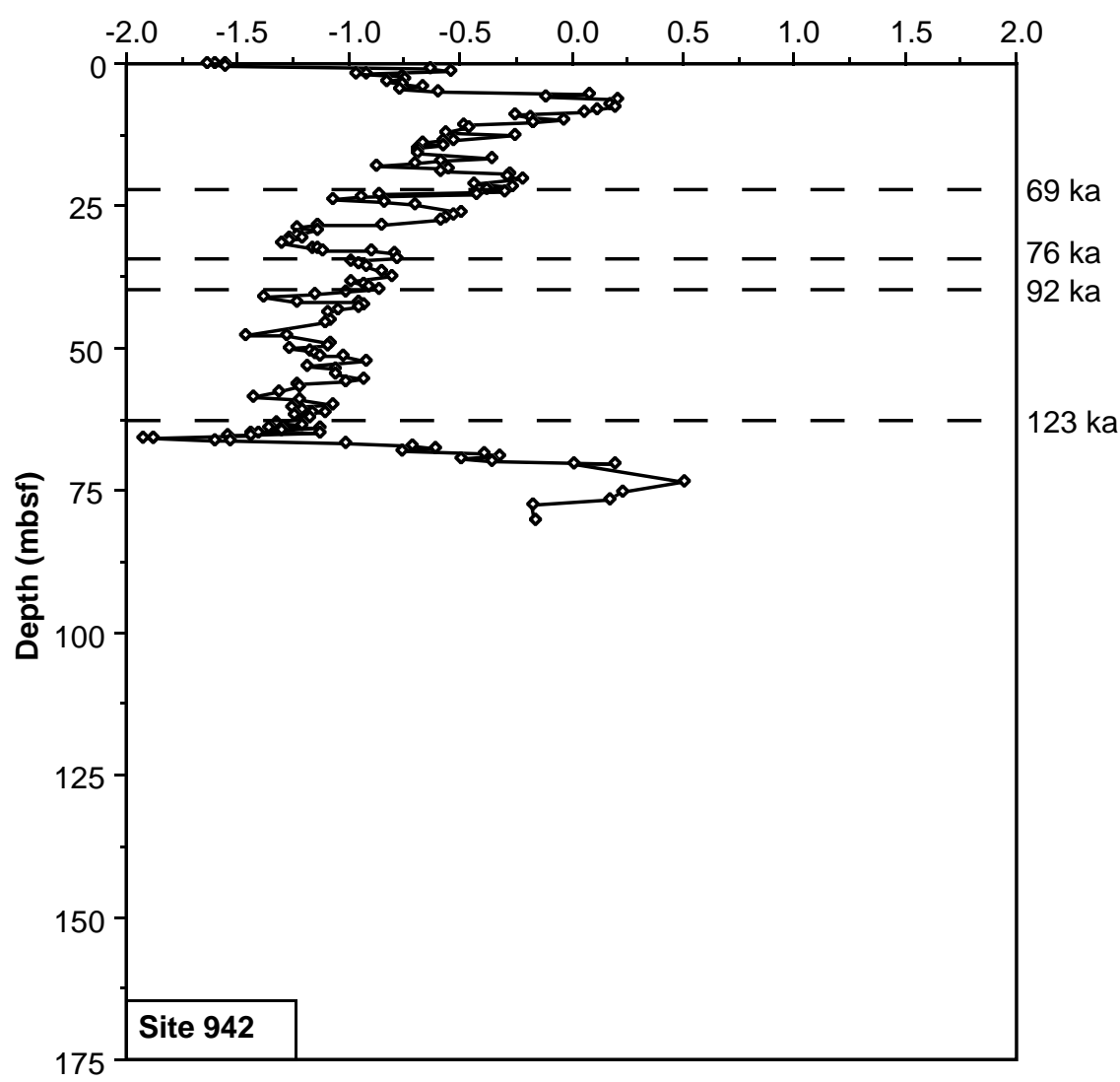

$$
\begin{array}{ll}
\longrightarrow & \text { G. trilobus } \\
\square & \text { N. dutertrei }
\end{array}
$$

Figure 9. Oxygen isotope stratigraphy of planktonic foraminifers from (A) Site 932 (Maslin et al., this volume), and (B) Site 942 (Showers et al., this volume). Dashed lines represent the boundaries between the subunits identified in previous figures, and the ages of these boundaries are as described in the text. 